\title{
IMPACT OF SCHOOL-BASED SUPPORT ON EDUCATIONAL OUTCOMES OF TEEN-MOTHERS: EVIDENCE FROM LINKED ADMINISTRATIVE DATA
}

\author{
Rhema Vaithianathan, School of Economics, Auckland University of Technnology (AUT) ${ }^{1}$ \\ Tim Maloney, School of Economics, AUT \\ Moira Wilson, New Zealand Ministry of Social Development \\ Anita Staneva, School of Economics, AUT \\ Nan Jiang, School of Economics, AUT
}

June 2017

\footnotetext{
${ }^{1}$ Please send correspondence to: Professor Rhema Vaithianathan, Centre for Social Data Analytics, School of Economics, Auckland University of Technology, Private Bag 92006, Auckland, NEW ZEALAND, or email: rhema.vaithianathan@aut.ac.nz.
} 


\section{Acknowledgements}

This research was supported by funding from the New Zealand Ministry of Social Development (MSD) and in-kind contributions from AUT and MSD. The authors gratefully acknowledge the assistance and advice provided by the many people who helped at different stages of the project. Particular thanks are due to Associate Professor Tue Gørgens (Australian National University), Dr Dean Hyslop (Motu Economic and Public Policy Research), and Professors Steven Durlauf and Christopher Taber (University of Wisconsin). We gratefully acknowledge the support provided in New Zealand by Rissa Ota (MSD), Sarah Tumen (Treasury) and Ashlee Cuneen (Ministry of Education).

\section{Agency Disclaimers}

The results in this paper are not official statistics. They have been created for research purposes from the Integrated Data Infrastructure (IDI), managed by Statistics New Zealand. The opinions, findings, recommendations, and conclusions expressed in this paper are those of the authors, not Statistics NZ. Access to anonymized data used in this study was provided by Statistics New Zealnd in accordance with security and confidentiality provisions of the Statistics Act 1975. Only people authorized by the Statistics Act 1975 are allowed to see data about a particular person, household, business, or organization, and the results in this paper have been confidentialized to protect these groups from identification.

Careful consideration has been given to the privacy, security, and confidentiality issues associated with using administrative and survey data in the IDI. Further detail can be found in the Privacy impact assessment for the Integrated Data Infrastructure available from www.stats.govt.nz. Ethics approval was granted by the Central Health and Disability Committee (Reference 14/CEN/95AM01).

\section{Note on Random Rounding}

All counts presented in this study have had Statistics New Zealand confidentiality rules applied. This includes the random rounding of all counts to base three. Therefore, the sample counts presented are not exact, and in some cases aggregating sub-samples will not yield the exact population counts. 


\begin{abstract}
Teen Parent Units (TPUs) provide support for high school students who are pregnant or parents in New Zealand. They provide childcare for the babies (often on-site), subsidized transport, links to health and other social services, as well as guidance and mentoring. Because this program is only available in some high schools, evaluation of the program is possible using teen mothers and schools in other geographic areas as controls. Using administrative data that links every child in the school system with maternity records, this study evaluates the impact of this program on school attendance and completion outcomes amongst nearly all teen mothers born between 1991 and 1994. We find that young women who had access to TPUs were less likely to dropout and more likely to complete school qualifications. Among all teen mothers, access to a TPU at or prior to conception significantly increased the probability of school enrollment after giving birth. Among teen mothers enrolled in school post-birth, TPU access substantially increased the probabilities of completing formal high school qualifications.
\end{abstract}




\section{Introduction}

The causal impacts of a teenage birth on economic outcomes such as education and wages are a point of contention amongst scholars. Simple correlations show that teen mothers have substantially worse economic outcomes. However, it is likely that teen mothers are from a selected sample of the population who would have had poorer outcomes even if they had delayed childbirth beyond their teenage years. In summarizing the literature, Kearney and Levine conclude that a "substantial majority of the observed correlation between teen childbirth and inferior outcomes is the result of underlying differences between those who give birth as a teen and those who do not." (p.161, 2014).

New Zealand, with its high teenage birth rates and concentration of teen births amongst economically deprived populations, has taken a two-track approach. While introducing some policies designed to reduce teen pregnancies, the Government has also tried to minimize the disruption in education for young women enrolled in school before giving birth, and to promote second-chance learning for young women who were disengaged from schooling prior to the birth of their child. As the Families Commission overview of teenage pregnancy and parenting noted, teen mothers often struggle to maintain engagement with school. "Inflexible school policies and procedures, a lack of adequate childcare and other practical difficulties make continuing education in mainstream schools very difficult.” (p.15, 2011).

This paper evaluates a unique intervention in New Zealand, where some teenage mothers have the opportunity to receive their schooling at Teen Parent Units (TPUs). These TPUs were specifically designed for teenagers who are pregnant or already parents. They provide childcare for the babies (often on-site), subsidized transport, links to health care and other social services, and guidance and mentoring.

Evaluation of this intervention helps to establish whether poor schooling outcomes for teen mothers can be offset through schooling opportunities that are designed around the needs of young mothers. Our study uses both distance to the nearest TPU school, as well as enrollment in a TPU school prior to conception, as proxies for access. Since TPUs are not available across all areas of the country, some young women have no access to a TPU in the surrounding area. We compare enrollment rates and educational qualifications of teen mothers in close proximity to a TPU to those further afield. We use linked administrative data for this study, which allows 
us to track a near census of young women through their school-age years and observe their birth and educational outcomes.

Our findings are consistent with TPUs having two effects on the educational outcomes for teen mothers: they increase enrollment rates, and raise the probabilities of attaining formal high school qualifications once enrollment has taken place.

This paper is organized as follows. In Section 2, we outline some details of how TPUs function. Section 3 briefly reviews the existing evidence on similar programs and their estimated effects. Section 4 outlines the construction of the data used in this study. Sections 5 and 6 contain the main parts of our analysis, which also includes a discussion on some limitations of this study. Conclusions appear in Sections 7 and 8. The Appendix contains supplementary tables and a map detailing the names and locations of the TPUs across the country.

\section{Teen Parent Units}

TPUs are separate administrative units overseen by public high schools (also known as 'TPU governing schools'). Most units are sited within these public high schools, but some are located off school grounds. TPUs enroll pregnant and parenting teenagers who are taught by registered teachers according to their individual needs. ${ }^{2}$ They may also be enrolled at Te Kura - The Correspondence School, to ensure access to a wide range of curriculum areas. In these situations, courses are supervised by TPU teachers, but teaching resources and evaluations are provided remotely. In some cases, students may also access classes on-site at the governing school. Apart from the standard high school curriculum, students in these units receive pastoral care and additional lifestyle courses (such as budgeting training). TPUs also provide early childhood education for the children (often on-site) and transport services, and commonly have close links with other community programs such as home-visiting services and community health services.

The first TPU was setup in Porirua in 1994 (Baragwanath, 1997). New units have been progressively established since then in other parts of the country. The creation of TPUs are driven by community interests and national needs. Before establishing a new unit, there needs to be interest from a potential governing school, evidence that a minimum of 15 students are ready to enrol, indications of longer-term roll sustainability, confirmation of space availability

\footnotetext{
${ }^{2}$ While teen fathers are also able to enroll, in practice few attend these units (Families Commission, 2011).
} 
to accommodate a TPU, and links with a local early childhood education service. The Ministry of Education is the final arbiter on resourcing for a new unit. There are only 23 TPUs across New Zealand and teen parents in many parts of the country did not have access to these units. ${ }^{3}$

Initial development and design of TPUs was informed by specialized "schools-within-schools" operating in the United States (Baragwanath, 1997). There have been few robust studies of the effectiveness of these schools, or other United States school-based interventions for adolescent parents and their children (Lachance et al., 2012; Pinzon and Jones, 2012; Seitz and Apfel, 1999). Some of the strongest evidence that specialized school-based services can improve outcomes comes from an evaluation of the New Haven McCabe Centre, a school for pregnant teenagers. Women whose enrollment in the school was delayed due to the long summer vacation were more likely than other enrollees to have pre-term births. Maximum possible durations of enrollment in school were, in effect, randomly allocated because students were only allowed to attend until the end of the school quarter in which their babies were born. After disregarding students who dropped out early, those allowed to remain in the school longer than seven weeks post-birth were less likely to have a subsequent child after a five-year follow-up compared to those who were allowed to remain for a shorter period. In addition, for students who had been performing poorly prior to becoming pregnant, there was a positive association between the length of time they were allowed to attend and their educational outcomes (Seitz and Apfel, 1999).

Other programs that are not school-based, but have some similarities to TPUs in the package of support services that they provide, have been examined in a series of randomized controlled trials. A systematic review by Harden et al. (2006) found that programs for teenage mothers that encouraged them to go back to school or college and provided assistance with childcare were successful in encouraging participation in education or training. High-quality programs that focused on young mothers' education and career development without use of sanctions were more effective than those that used sanctions and incentives as part of the intervention. Across both types of programs (those that used sanctions and incentives, and those that focused on education and career development), positive effects on participation in education and training did not necessarily translate into better rates of employment in the short-

\footnotetext{
${ }^{3}$ See Figure $1 \mathrm{~A}$ and Table $1 \mathrm{~A}$ in the Appendix for details on the locations of these units.
} 
term. Young mothers in the intervention and control groups had very similar employment rates two to four years later (Harden et al., 2006).

\section{$3 \quad$ Linked Administrative Data}

The data used in this study are from a de-identified linkage involving administrative data held by New Zealand Government. Included in the linkage are data from the Ministry of Education, which covers private, public, correspondence, denominational and special schools (i.e., all registered schools in the country). ${ }^{4}$ The Ministry of Education data covered all registered schools by the end of 2017. These data include enrollment episodes, with the start and finish spells at each school in which the student was enrolled, and all formal qualifications attained. The data for our study were extracted in April 2014.

To be included in our study, a young woman must have been born between 1 January 1991 and 31 December 1994, and enrolled in a New Zealand school for at least one day before 1 January $2008 .^{5}$ This yields 125,760 young women in our study sample.

To establish the comprehensive nature of these data, we compare our study sample with the estimated national population as of 1 December 2006 in Table 1. We have only partial cohorts for both 12 and 16 year olds. These figures indicate that we have around 1,000 more females in our sample at ages 13 through 15 compared to the population estimates at these ages by Statistics New Zealand. Discrepancies could be due to young women migrating to New Zealand between December 2006 and January 2008 who would be included in our data but not necessarily in the population estimates. However, Table 1 suggests that our method of constructing this cohort captures near census-level data for the relevant female-age population.

To identify teen mothers, schooling data were linked with Ministry of Health maternity data using first name, last name and date of birth. ${ }^{6}$ Births in maternity data were identified as a result of either a lead maternity carer's claim for payment, or a publicly-funded hospital event. Because maternity services in New Zealand are publicly funded and provided universally free

\footnotetext{
${ }^{4}$ Home schooled young women (and those who are in casual, unregistered schools) are not included in our dataset.

${ }^{5}$ We drop women whose first enrollment records were after 1 January 2008, because we assume that these young women were immigrants and we therefore cannot tell if they had given birth prior to entering the country. ${ }^{6} \mathrm{New}$ Zealand does not have a unique person identifier that applies across all government databases. All data were de-identified prior to our analysis, and accessed by the research team through the secure Statistics New Zealand Datalab and a secure server at the Ministry of Social Development. More details on the data linkage history and protocols can be found at http://www.msd.govt.nz/about-msd-and-our-work/publicationsresources/evaluation/family-start-outcomes-study/index.html.
} 
of charge, these data capture virtually all births. We define a teen mother as a woman having a live birth between her $13^{\text {th }}$ and $19^{\text {th }}$ birthdays, and we restrict attention to first births. This yields observations on 6,711 young women in our cohort who had a teen birth.

Table 1: Study Cohort and Estimated Resident Female Population

\begin{tabular}{c|c|c}
\hline $\begin{array}{c}\text { Age as of } \\
\text { 1 December 2006 }\end{array}$ & $\begin{array}{c}\text { Study } \\
\text { Population }\end{array}$ & $\begin{array}{c}\text { Population } \\
\text { Estimates }\end{array}$ \\
\hline 12 & 18,369 & Not comparable \\
\hline 13 & 30,765 & 30,580 \\
\hline 14 & 31,143 & 30,730 \\
\hline 15 & 32,043 & 31,540 \\
\hline 16 & 13,440 & Not comparable \\
\hline Ages 12-16 & 125,760 & Not comparable \\
\hline
\end{tabular}

Notes: The final column lists the estimated resident female population by individual ages as of 1 December 2006. These data were downloaded from the Infoshare website of Statistics New Zealand on 20 January 2016. Table reference DPE058AA.

Other administrative data were linked to establish a range of control variables. These include indicators of past involvement with either the Child Youth and Family care and protection, the Youth Justice system, and proportion of time during the first five year of life that the teenager was living in a household that received a social welfare benefit. These histories were observed for young women prior to giving birth. Additional control variables include the young woman's prioritised ethnicity, and school characteristics (school enrollment and decile, and regional office for the Ministry of Education in which the school was located). ${ }^{7}$

Our outcomes of interest in this study are school enrollment status for young women after giving birth and their subsequent attainment of National Certificate of Educational Attainment (NCEA) Level 1 and 2 qualifications. While schooling is compulsory in New Zealand until the $16^{\text {th }}$ birthday, approximately 83 percent of students remain in school until at least their $17^{\text {th }}$ birthdays. ${ }^{8}$ The NCEA system is New Zealand's main national qualification standard for secondary students, and based on national subject exams administered at the end of years 11, 12 and 13 in high school (equivalent to sophomore, junior and senior years in the US school system). Students who receive specified credits from these internal and external assessments

\footnotetext{
${ }^{7}$ School deciles are used to target funding at disadvantaged schools in New Zealand. Schools are allocated to deciles based on the socio-economic status of the communities from which their students are drawn. For more information see: http://www.education.govt.nz/school/running-a-school/resourcing/operational-funding/schooldecile-ratings/\#About

${ }^{8}$ See http://www.educationcounts.govt.nz/indicators/main/student-engagement-participation/1955.
} 
in approved subjects are granted NCEA Level 1, 2 and 3 qualifications. ${ }^{9}$ We ignore NCEA Level 3 qualifications, which are generally required for university entrance, and concentrate on the attainment of Level 1 and 2 qualifications, which are typically received by ages 16 and 17 , respectively. We were able to access data that provided detailed information about the standards and associated credits achieved by each student. Using information about how credits translate into qualifications, we were able to determine whether these students received these qualifications and the calendar year in which they were completed. This allows us to estimate whether the young mothers in our study obtained these school qualifications after giving birth.

Given the constraints of the data linkage, not all of our study sample participants are seen for the whole period of the study. Table 2 provides a breakdown of the degree of censoring that applies to each birth cohort in the study. Data for the 1991 cohort are censored at the start in that they only first enter the Ministry of Education data at ages 14 and 15. Data for some members of the 1994 cohort are censored because we do not observe them in the maternity data right up to their $19^{\text {th }}$ birthday. All of the controls used in our regression analysis for cohort effects account for this censoring. Controlling for birth cohorts also serves the purpose of taking into account the steep decline in teenage births that occurred over the study period (see Figure 2A in the Appendix), and the growth in the rates of retention in school and attainment of NCEA qualifications for recent cohorts. ${ }^{10} \mathrm{We}$ test the robustness of our results to censoring through re-estimating our baseline models on restricted sub-samples for which all data were uncensored.

Table 2: Censoring of Study Sample

\begin{tabular}{c|c|c|c|c}
\hline Year Born & $\begin{array}{c}\text { Age at start of 2006 when } \\
\text { Ministry of Education data } \\
\text { are first available }\end{array}$ & $\begin{array}{c}\text { Age at end of 2007 when } \\
\text { Ministry of Education data } \\
\text { have full coverage }\end{array}$ & $\begin{array}{c}\text { Age last seen in } \\
\text { Maternity data } \\
\text { (3 June 2012) }\end{array}$ & $\begin{array}{c}\text { Age last seen in } \\
\text { Education data } \\
\text { (11 April 2014) }\end{array}$ \\
\hline 1991 & $14-15$ & $16-17$ & $20.5-21.5$ & $22.25-23.25$ \\
\hline 1992 & $13-14$ & $15-16$ & $19.5-20.5$ & $21.25-22.25$ \\
\hline 1993 & $12-13$ & $14-15$ & $18.5-19.5$ & $20.25-21.25$ \\
\hline 1994 & $11-12$ & $13-14$ & $17.5-18.5$ & $19.25-20.25$ \\
\hline
\end{tabular}

\footnotetext{
${ }^{9}$ For more information on the NCEA system see: http://www.nzqa.govt.nz/qualificationsstandards/qualifications/ncea/understanding-ncea.

${ }^{10}$ See http://www.educationcounts.govt.nz/indicators/main/student-engagement-participation/1955 and http://www.educationcounts.govt.nz/indicators/main/education-and-learning-outcomes/28788.
} 
Table 3 compares the descriptive statistics for teenage mothers with the rest of the young women observed in our birth cohorts. We observe teen births for 6,711 young women prior to their $19^{\text {th }}$ birthdays. They represent over 5.3 percent of the 125,763 females in our dataset. The characteristics of teen mothers are quite different to other female teenagers from the same birth cohorts. Teen mothers are relatively more likely to be from Maori or Pacific ethnic minority groups, and less likely to report Asian ethnicity. They were relatively more likely to have been placed in Child, Youth and Family care or referred to the youth justice system prior to the birth of the child. They were relatively more likely to have attended low-decile schools (i.e., the lowest $30 \%$ of schools by socio-economic status).

Table 3: Selected Characteristics of Study Samples

\begin{tabular}{l|c|c|c}
\hline Variables & $\begin{array}{c}\text { Teen } \\
\text { Mothers }\end{array}$ & $\begin{array}{c}\text { Remainder } \\
\text { of Sample }\end{array}$ & $\begin{array}{c}\text { Full } \\
\text { Sample }\end{array}$ \\
\hline European & 0.447 & 0.651 & 0.640 \\
\hline Māori & 0.524 & 0.199 & 0.216 \\
\hline Pacific & 0.127 & 0.096 & 0.098 \\
\hline Asian & 0.015 & 0.105 & 0.101 \\
\hline Other ethnicity & 0.011 & 0.024 & 0.023 \\
\hline Main urban area & 0.672 & 0.751 & 0.747 \\
\hline Minor urban area & 0.152 & 0.115 & 0.117 \\
\hline Rural area & 0.029 & 0.029 & 0.029 \\
\hline $\begin{array}{l}\text { Ever placed in care of } \\
\text { Child, Youth and Family }\end{array}$ & 0.129 & 0.023 & 0.029 \\
\hline $\begin{array}{l}\text { Ever Youth Justice } \\
\text { involvement }\end{array}$ & 0.127 & 0.017 & 0.023 \\
\hline School deciles 1 to 3 & 0.359 & 0.185 & 0.195 \\
\hline$n$ & 6,711 & 119,052 & 125,763 \\
\hline
\end{tabular}

\section{$4 \quad$ TPUs and Educational Outcomes for Teen Mothers}

We now turn to the primary purpose of this study, which is to evaluate the impact of access to a TPU on educational outcomes for young women who have given birth. Consider the following regression model:

$$
\operatorname{Pr}(Y=1)=\Phi\left(\beta_{0}+\beta_{1} X+\beta_{2} T P U_{\text {Access }}\right)
$$

where $Y$ is a dummy variable that takes on a value of one if an individual was either enrolled in school or completed an NCEA qualification post-birth; zero otherwise. The vector $X$ includes a range of individual, school and area control variables, and $T P U_{A c c e s s}$ is an indicator 
variable on whether or not the young woman had access to a TPU. The probabilities of a teen mother being in school or completing an NCEA qualification come from the cumulative density function of the standard normal $\Phi(\cdot)$. The coefficient $\beta_{2}$ is the parameter of interest. We hypothesize that access to a TPU will increase the probabilities of both post-birth school enrollment and completion of NCEA Level 1 and 2 qualifications (i.e., $\left.\beta_{2}>0\right){ }^{11}$

The most robust way to produce unbiased estimates of these effects would be to provide access to TPUs for a randomly selected group of teen mothers (i.e., the treated group), and to compare their outcomes to those who did not receive any access (i.e., the control group).

As it happens, TPU coverage across the country is incomplete (see the Figure 1A in the Appendix) and the access for young women depends largely on where they lived while attending high school. Some geographic regions have no TPUs and the women who gave birth in these areas provide a useful set of controls. Moreover, prior to becoming pregnant some young women were enrolled in schools that happened to be TPU governing schools. These young women had easy access to a TPU since they did not have to change schools after giving birth. For a third group of young women, a TPU was accessible because they lived within a reasonable commuting distance of a unit. We therefore have an opportunity to exploit whether they were enrolled in a TPU governing school prior to pregnancy and the distance to the nearest TPU as proxies for access.

We estimate the following model:

$$
\operatorname{Pr}(Y=1)=\Phi\left(\beta_{0}+\beta_{1} X+\beta_{2} T P U_{20 K M}+\beta_{3} T P U_{\text {Pre-Birth }}\right)
$$

Where for the most recent school in which the young woman was enrolled at or prior to conception was either located within 20 kilometers of a TPU governing school $\left(T P U_{20 K M}=\right.$ $1)$, or was itself a TPU school $\left(T P U_{\text {Pre-Birth }}=1\right)$; zero otherwise for both dummy variables. Our evaluation approach tests whether $\beta_{2}$ or $\beta_{3}$ are individually and jointly significantly different from zero.

This approach only yields unbiased estimates if distance to a TPU is conditionally independent of outcomes for young women who gave birth. Note that the requirement is a conditional

\footnotetext{
${ }^{11}$ Because this is a nonlinear regression model, we cannot interpret the coefficients as the change in the probability of this outcome for a change in the value of this dummy independent variable. This requires the computation of partial derivatives of this cumulative standard normal. We report the sample mean of these estimated marginal effects in all subsequent tables.
} 
independence - this includes being conditional on a young woman giving birth. If the presence of a TPU differentially selects young women into birth, then our strategy might yield biased estimates if there exist unobserved characteristics that influence selection and the outcome of interest. For example, if the presence of a TPU encourages more motivated young women to deliver a child after pregnancy then the estimated effect of the TPU on schooling would be biased upwards. The sign of this potential is unclear a priori. In any case, we address these potential contamination issues later by undertaking a series of robustness tests.

In constructing the distance dummy $\left(T P U_{20 K M}\right)$, we do not have information on the young woman's home address and therefore use distance between the most recent school in which the young woman was enrolled at the date of conception and the closest TPU. For those young women who were not enrolled at the time of conception, we use the distance of the last school in which they were enrolled prior to conception. We use a proximity measure as less than 20 kilometers driving distance from the conception school. ${ }^{12}$

We define a conception date as the (approximate) date on which the young woman conceived using maternity data, which provides information on the gestational age of the baby at birth. By subtracting the gestational age from the baby's date of birth, we are able to establish the approximate date of conception.

\subsection{Enrollment Patterns of Young Mothers}

Before turning to our results, it is useful to understand the enrollment patterns of young women in our sample who gave birth. For this purpose, we define a young woman's enrollment status at conception as: (i) Enrolled in a TPU governing school; (ii) Enrolled in a non-TPU school; or (iii) Unenrolled.

Unenrolled is defined as applying where the young woman was not enrolled in a school at the estimated date of conception. We find that some of our young women terminate an enrollment spell in December (when the school year ends), and then re-enroll in February after the summer break (although this is not the case for the majority of young women who are officially recorded as being enrolled through the summer break). In the case of these individuals classified as unenrolled during summer, if the young woman conceived during this summer period we

\footnotetext{
${ }^{12}$ We used a 'macro' that Google Searches the origin and destination and returns the corresponding distance between the TPU governing school and conception school locations in kilometers. Where the physical address of the governing school was different to the physical address of the TPU, we use the physical address of the TPU.
} 
cannot know if she was intending to return to school. In the descriptive statistics shown in Table 4, we consider her unenrolled if she was unenrolled at the start of the summer in which she conceived (i.e. we assume she would not have re-enrolled after the summer). We test the robustness of our results by also excluding young women who conceived during the summer break.

A young woman's post-birth enrollment status can be defined as: (i) Enrolled in a TPU governing school; ${ }^{13}$ (ii) Enrolled in a non-TPU school; or (iii) Unenrolled. We prioritize TPU school enrollment, so that a young woman who has at some point enrolled in a TPU governing school after the birth of her child is classified as having enrolled in a TPU school. If she enrolled after birth but never enrolled in a TPU school, we classify her as enrolled in a non-TPU school.

Table 4: Proportion of Teen Mothers Enrolled in School at Conception by Age at First Birth

\begin{tabular}{|c|c|c|c|c|c|c|}
\hline \multirow{2}{*}{$\begin{array}{l}\text { Mother's age at } \\
\text { first birth }\end{array}$} & \multicolumn{2}{|c|}{$\begin{array}{l}\text { All teen mothers } \\
\text { enrolled in school at } \\
\text { conception }\end{array}$} & \multicolumn{2}{|c|}{$\begin{array}{l}\text { Excluding mothers } \\
\text { with summer } \\
\text { conception dates }\end{array}$} & \multicolumn{2}{|c|}{$\begin{array}{l}\text { Conceived in } 2008 \text { or } \\
\text { later and excluding } \\
\text { mothers with summer } \\
\text { conception dates }\end{array}$} \\
\hline & Proportion & $n$ & Proportion & $n$ & Proportion & $n$ \\
\hline 13 & \multicolumn{2}{|c|}{ Too few for display } & \multicolumn{2}{|c|}{ Too few for display } & \multicolumn{2}{|c|}{ Too few for display } \\
\hline 14 & 0.59 & 111 & 0.68 & 99 & \multicolumn{2}{|c|}{ Too few for display } \\
\hline 15 & 0.75 & 465 & 0.79 & 438 & 0.82 & 183 \\
\hline 16 & 0.60 & 1,254 & 0.64 & 1,170 & 0.65 & 801 \\
\hline 17 & 0.32 & 2,355 & 0.37 & 2,055 & 0.36 & 1,920 \\
\hline 18 & 0.19 & 2,514 & 0.21 & 2,187 & 0.21 & 2,187 \\
\hline All & 0.35 & 6,711 & 0.40 & 5,958 & 0.36 & 5,112 \\
\hline
\end{tabular}

Notes: Summer conception is defined as the baby being conceived inter alia between December and February. Conception date is calculated as birth date minus weeks of gestation as recorded in Ministry of Health maternity data.

Table 4 describes the conception status of teen mothers including and excluding those who conceived during the summer. We also calculate similar statistics for young women who conceived in 2008 or later to address the concerns about data censoring based on possibly incomplete data on enrollment status for those who conceived in 2006 and 2007. For the sample as a whole, between 35 and 40 percent of young women were enrolled when they

\footnotetext{
${ }^{13}$ We do not know if a young woman was attending TPU classes, only that she was enrolled in a TPU governing school. However, it would be very rare for a teen mother not to attend a TPU if it was available.
} 
conceived (depending on the definition of enrollment). The lower proportion is for the sample as a whole where we consider young women unenrolled if they were officially designated as unenrolled at the start of the summer in which they conceived. Ignoring those who conceived during the summer months increases the proportion who were enrolled at conception to 40 percent.

At least from age 15, the proportion of young women enrolled at conception falls with the increasing age of the mother at birth. Because they avoid the period for which data capture is incomplete, rates for those who conceived in 2008 or later provide the best estimates of nonenrollment at ages when school enrollment would be expected to be high. Ignoring those who conceived during the summer months, among young women at age 15 who had their first birth, 18 percent were not enrolled in school at conception. For mothers at age 16 with their first birth, 35 percent were not enrolled in school at conception (most of whom would have been of compulsory schooling age at conception). Consistent with findings for the Christchurch birth cohort (Woodward and Fergusson, 1999; Fergusson and Woodward, 2000), the enrollment status of the young women who gave birth before age 19 shows that these young women had low levels of engagement with schooling even prior to giving birth.

Table 5: Proportion of Teen Mothers Enrolled Post-Birth by Age at First Birth

\begin{tabular}{c|c|c}
\hline $\begin{array}{c}\text { Mother's age at } \\
\text { first birth }\end{array}$ & $\begin{array}{c}\text { Proportion } \\
\text { Enrolled at some } \\
\text { point after birth }\end{array}$ & $n$ \\
\hline 13 & \multicolumn{2}{|c|}{ Too few for display } \\
\hline 14 & 0.97 & 111 \\
\hline 15 & 0.85 & 465 \\
\hline 16 & 0.54 & 1,254 \\
\hline 17 & 0.35 & 2,355 \\
\hline 18 & 0.14 & 2,514 \\
\hline All & 0.35 & 6,711 \\
\hline
\end{tabular}

Notes: Post-birth enrollment is defined as having at least one day's enrollment in a school after the birth of the baby and before April 2014 (when the data from the Ministry of Education end).

Table 5 displays the post-birth enrollment status of the teen mothers. As expected, only a small group have any enrollment after giving birth (35 percent). However, this post-birth enrollment status declines substantially with the mother's age at first birth. 
Table 6 provides the cross-tabulation between enrollment status at conception and post-birth. Not surprisingly, young women who were enrolled at conception were considerably more likely to be enrolled after birth (59 percent) compared to young women who were not enrolled at conception (22 percent). Overall, more young mothers were enrolled post-birth in a nonTPU school compared to a TPU school. This is not surprising given that there are relatively few TPUs in the country.

Table 6: Enrollment Status of Teen Mothers at Conception and Post-Birth

\begin{tabular}{|c|c|c|c|c|}
\hline \multirow[b]{2}{*}{ Enrollment status at conception } & \multicolumn{4}{|c|}{ Enrollment status post-birth } \\
\hline & Unenrolled & $\begin{array}{l}\text { TPU governing } \\
\text { school enrolled } \\
\end{array}$ & $\begin{array}{c}\text { Non-TPU school } \\
\text { enrolled }\end{array}$ & Row totals \\
\hline Unenrolled & $\begin{array}{c}0.78 \\
n=3,366\end{array}$ & $\begin{array}{c}0.11 \\
n=486\end{array}$ & $\begin{array}{c}0.11 \\
n=477\end{array}$ & $\begin{array}{c}1.00 \\
n=4,329\end{array}$ \\
\hline TPU governing school enrolled & $\begin{array}{c}0.31 \\
n=87\end{array}$ & $\begin{array}{c}0.59 \\
n=168\end{array}$ & $\begin{array}{c}0.11 \\
n=30\end{array}$ & $\begin{array}{c}1.00 \\
n=285\end{array}$ \\
\hline Non-TPU school enrolled & $\begin{array}{c}0.42 \\
n=882\end{array}$ & $\begin{array}{c}0.21 \\
n=444\end{array}$ & $\begin{array}{c}0.36 \\
n=759 \\
\end{array}$ & $\begin{array}{c}1.00 \\
n=2,085 \\
\end{array}$ \\
\hline Missing & \multicolumn{3}{|c|}{ Too few to report } & $n=15$ \\
\hline Column totals & $\begin{array}{c}0.65 \\
n=4,335\end{array}$ & $\begin{array}{c}0.16 \\
n=1,104\end{array}$ & $\begin{array}{c}0.19 \\
n=1,260\end{array}$ & $\begin{array}{c}1.00 \\
n=6,711\end{array}$ \\
\hline
\end{tabular}

Notes: There were 15 observations with missing enrollment status at conception. TPU enrollment is prioritized so that a young woman who has at some point enrolled in a TPU governing school after the birth of her child is classified as enrolled in a TPU school post-birth. Where there is a summer conception date, we consider young women unenrolled if they were unenrolled at the start of the summer in which they conceived.

An interesting statistic is to compare post-birth enrollment rates between the 285 young women who were enrolled in a TPU governing school at conception with the 2,085 young women who were enrolled in a non-TPU school when they conceived. The post-birth enrollment rate for the former is 70 percent whereas for the latter it is 58 percent. Of course, there might be other differences between these schools - but if we assume that young women did not enroll in a TPU governing school in order to conceive, then this higher enrollment rate is suggestive of a positive impact of TPUs. ${ }^{14}$ It should be noted that young women who conceived while attending a TPU governing school can switch enrollment to a non-TPU school post-birth (11 percent). However, young women who conceive while attending a non-TPU school are nearly twice as likely to switch enrollment to a TPU governing school (21 percent). This is despite the fact that there are relatively fewer TPU governing schools and they are non-existent in

\footnotetext{
${ }^{14}$ We recalculated these rates for those young women who conceived in 2008 or later, and we can confirm that the results in Table 5 are not due to the censoring problem that we discussed earlier.
} 
many regions of the country. This is why we do not estimate these educational attendance and attainment effects based on enrollment in a TPU governing school post-birth. Potential sample selection effects in more motivated teen mothers migrating to these units could bias the estimated impacts of TPUs on the educational outcomes for teen mothers.

\subsection{Schooling Outcomes for Young Mothers and Proximity to a TPU}

We now turn to the results of estimating equation (2) for young women who have a teen birth. The vector $X_{i}$ include characteristics of the individual, school and geographic area. At the individual level, we include regressors on ethnicity, birth cohorts, previous involvement with both Child, Youth and Family care and protection and the Youth Justice system, and the proportion of time before the age of five that the young woman was living in a household in receiving a main welfare benefit (a proxy for early exposure to poverty). School level controls include dummies on the decile level of the first school in which the young woman was observed, and school enrollment size (measured in hundreds of students). Area variables include the rural or urban classification of the young woman's census area as at the time of her child's birth from the health data, and the school's regional office from the education data

Table 7 reports the key regression results where the outcome of interest is the probability that a young woman who had a teen birth was subsequently enrolled in any school (not just a TPU governing school) post-birth. ${ }^{15}$ The coefficients of interest to us are the effects of being less than 20 kilometers from a TPU governing school at or prior to conception, and enrolled in a TPU school at or prior to conception. The estimated effects suggest that being at a school within 20 kilometers of a TPU at conception increases overall post-birth enrollment by 3.9 percentage points compared to being at a school further than this distance away. This estimated effect is statistically different from zero at a $p$-value of 1.9 percent. Moreover, if the young woman was enrolled in a TPU governing school at or prior to conception, there is an additional 4.6 percentage-point increase in her post-birth enrollment probability ( $p$-value of 2.7 percent). The combined effects mean that the average teen mother's post-birth enrollment rate would be 8.5 percentage-points higher if she was enrolled in a TPU school at or prior to conception compared

\footnotetext{
15 There are 954 individuals with missing data on distance between conception school and the nearest TPU, which represents 14.2 percent of the sample. These observations were excluded from our regression analysis because of this key missing covariate. Complete sets of all regression results are available in the Appendix to this report. For example, the regression results associated with summary Table 7 can be found in Table 7A.
} 
to a teen mother whose school at or prior to conception was not within 20 kilometers of a TPU governing school.

Table 7: Marginal Effects for Teen Mothers on the Probability of Post-Birth School Enrollment

\begin{tabular}{|c|c|}
\hline Explanatory Variables & $\begin{array}{c}\text { Estimated effect on probability of } \\
\text { enrollment post-birth } \\
\text { [95\% confidence interval] } \\
\text { and } p \text {-value }\end{array}$ \\
\hline $\begin{array}{l}\text { TPU school }<20 \mathrm{~km}\left(T P U_{20 K M}\right) \\
\text { at or prior to conception }\end{array}$ & $\begin{array}{c}0.039^{* *} \\
{\left[\begin{array}{cc}0.006 & 0.072\end{array}\right]} \\
p=0.019\end{array}$ \\
\hline $\begin{array}{l}\left.\text { Enrolled in TPU school ( } T P U_{P r e-B i r t h}\right) \\
\text { at or prior to conception }\end{array}$ & $\begin{array}{c}0.046^{* *} \\
{[0.0050 .087]} \\
p=0.027\end{array}$ \\
\hline$n$ & 5,625 \\
\hline
\end{tabular}

Notes: ${ }^{*} p<0.10,{ }^{* *} p<0.05,{ }^{* * *} p<0.01$. Individuals whose distance from the nearest TPU is missing $(n=954)$ and where the Ministry of Education local office was missing $(n=123)$ were excluded from the regression. This table only reports the key findings from this analysis. A full set of regression results can be found in Table 7A in the Appendix.

Table 8 reports the key regression results for the completion of NCEA Level 1 and 2 qualifications by the end of the year in which the young woman turned 19. We only consider young women who had not yet attained sufficient credits to gain these qualifications by the end of the year in which they gave birth. ${ }^{16}$

Table 8: Marginal Effects on the Probabilities for Teen Mothers Completing NCEA Qualifications

\begin{tabular}{|c|c|c|}
\hline \multirow[b]{2}{*}{ Explanatory Variables } & \multicolumn{2}{|c|}{$\begin{array}{c}\text { Estimated effects on attaining school } \\
\text { qualifications by age } 19 . \\
\text { [95\% confidence interval] } \\
\text { and } p \text {-value } \\
\end{array}$} \\
\hline & NCEA Level 1 & NCEA Level 2 \\
\hline $\begin{array}{l}\text { TPU school }<20 \mathrm{~km}\left(T P U_{20 K M}\right) \\
\text { at or prior to conception }\end{array}$ & $\begin{array}{c}-0.005 \\
{[-0.0420 .032]} \\
p=0.789\end{array}$ & $\begin{array}{c}-0.002 \\
{[-0.0320 .028]} \\
p=0.891\end{array}$ \\
\hline $\begin{array}{l}\left.\text { Enrolled in TPU school ( TPU } U_{\text {Pre-Birth }}\right) \\
\text { at or prior to conception }\end{array}$ & $\begin{array}{c}0.043^{*} \\
{[-0.0010 .088]} \\
p=0.054\end{array}$ & $\begin{array}{c}0.035^{*} \\
{[-0.0010 .071]} \\
p=0.060\end{array}$ \\
\hline $\begin{array}{c}n \\
\text { Means of dependent variables }\end{array}$ & $\begin{array}{c}3,849 \\
0.27\end{array}$ & $\begin{array}{c}4,914 \\
0.21\end{array}$ \\
\hline
\end{tabular}

Notes: ${ }^{*} p<0.10,{ }^{* *} p<0.05,{ }^{* * *} p<0.01$. Individuals whose distance from the nearest TPU is missing $(n=954)$ and where the Ministry of Education local office was missing $(n=123)$ were excluded from the regression. This table only reports the key findings from this analysis. A full set of regression results can be found in Table $8 \mathrm{~A}$ in the Appendix.

\footnotetext{
${ }^{16}$ We are unable to estimate attainment prior to the exact date of first birth because we only have information about the calendar year in which credits were awarded.
} 
We find no statistical evidence that being located within 20 kilometers of a TPU governing school at or prior to conception influences the probability of eventually completing NCEA Level 1 and 2 qualifications. However, there is weak statistical evidence that being enrolled in a TPU school at or prior to conception has positive effects on the probabilities of obtaining these early high school qualifications. These estimated effects are 4.3 and 3.5 percentage points for NCEA Level 1 and 2 qualifications (associated $p$-values are 5.4 and 6.0 percent), respectively. Given that the rate of completion of NCEA Level 1 for teen mothers in our sample is only 27 percent, this point estimate represents a substantial impact on this school qualification rate (an increase of one-fifth). The estimated impact on NCEA Level 2 completion rate is approximately one-sixth. It is important to note, however, that these estimated effects of early exposure to a TPU school on subsequent attainment of school qualifications are measured considerable imprecision.

\subsection{Selection into Birth and Access to a TPU}

New Zealand has fairly permissive abortion laws. It's estimated that the proportion of teen pregnancies that end in abortion in New Zealand ranges from 65 percent among females aged 10 to 14 years old to 36 percent among females aged 15 to 19 years old (Sedgh et al., 2015). This poses a threat to the validity of our empirical strategy, because young women who lived in areas without TPUs faced different educational penalties from termination to those with ready access to TPUs. In particular, those with access to TPUs most likely have better postbirth schooling options.

Unfortunately, we do not have any information on pregnancies or terminations in the data available to us, and therefore we are unable to directly test whether access to a TPU has an impact on whether pregnancies are carried to term. However, an indirect test can be undertaken by estimating the following model for all young women who were enrolled in school at age 14 .

$$
\operatorname{Pr}(B I R T H=1)=\Phi\left(\gamma_{0}+\gamma_{1} Z+\gamma_{2} T P U_{a g e 14}\right)
$$

where BIRTH indicates whether or not a young woman became a teen mother, $Z$ are a set of control variables and TPU $U_{a g e 14}$ indicates whether the young woman was enrolled in a TPU governing school at age 14 (and prior to any conception). The sign of the coefficient $\gamma_{2}$ is of interest to us as it indicates whether easy access to a TPU increases the teenage birth rate. 
Table 9 reports the key results from this regression. ${ }^{17}$ We find that being enrolled in a TPU governing school at age 14 has no measureable effect on the probability of giving birth before age 19. The estimated coefficient is positive, but statistically insignificant at conventional test levels. This suggests that conditional on those risk factors included in the vector $Z$, there are no additional unobserved factors associated with enrollment in a TPU school at age 14 that influence the probability of having a teen birth.

\begin{tabular}{|c|c|}
\hline Explanatory Variable & $\begin{array}{l}\text { Estimated effect on probability } \\
\text { of a teen birth } \\
\text { [95\% confidence interval] } \\
\text { and } p \text {-value } \\
\end{array}$ \\
\hline Enrolled in TPU school at age $14\left(\mathrm{TPU}_{\text {age } 14}\right)$ & $\begin{array}{c}0.002 \\
{[-0.0020 .005]} \\
p=0.332\end{array}$ \\
\hline$n$ & 81,129 \\
\hline
\end{tabular}

Notes; ${ }^{*} p<0.10,{ }^{* *} p<0.05,{ }^{* * *} p<0.01$. Individuals whose the Ministry of Education local office is missing $(n$ $=123$ ) were excluded from the regression. This table only reports the key findings from this analysis. A full set of regression results can be found in Table 9A in the Appendix.

\section{$5 \quad$ Impact of TPU vs. Non-TPU Schools}

The previous section presented results that suggested that early access to a TPU governing school does have measureable effects on NCEA attainment. There are potentially two ways in which access to a TPU could improve qualifications. One is that access to a TPU could result in more young women enrolling in school after birth. The other effect is that once teen mothers are enrolled, TPUs might be more successful than mainstream schools at supporting them to achieve NCEA qualifications.

In this section, we consider the impact on NCEA achievement of enrolling in a TPU schools vs. non-TPU schools. However, this causal effect is easy to identify because there are likely to be unobservable factors that have impacts on both post-birth enrollment and NCEA attainment.

17 The set of controls are only a subset of the controls used in the previous regressions. The reason is that we have richer set of controls for young women who gave birth compared to all who are in the enrollment data because we are able to draw on maternity data for young women who gave birth. 
For example, consider estimating the following simple regression model on those young women who enroll in a school after they give birth:

$$
\operatorname{Pr}(N C E A=1)=\Phi\left(\beta_{1}+\beta_{2} T P U\right)
$$

where NCEA is the outcome of interest, and TPU is equal to 1 if the young woman enrolls in a TPU school after giving birth, and zero if she enrols in a non-TPU school post-birth.

The problem with interpreting $\beta_{2}$ as the causal effect of enrolling in a TPU vs. non-TPU school is that students who attend TPU schools may be those who face unusually low (or high) propensities to complete NCEA qualifications. To the extent that this propensity is unobserved, it's captured in the error term and the TPU variable and disturbances would be negatively (positively) correlated. This would bias downward (upward) the estimator for $\beta_{2}$. Therefore, we use an Instrumental Variable (IV) method to mitigate this bias and produce the causal inference that we want. ${ }^{18}$

We use distance (in kilometers) to the nearest TPU school at or prior to conception and enrollment in a TPU school at or prior to conception as the two valid instruments for this analysis. The main exclusion restriction is the assumption we have maintained throughout this paper - which is that the presence of TPU access at or prior to conception does not affect the decisions of young women to continue their pregnancies to term. Indeed, we provided some earlier evidence that young women who were enrolled in TPU at age 14 did not influence the teen birth rate after controlling for other characteristics.

Table 10 provides the main results for two sets of maximum likelihood probit estimates on the probabilities of completing NCEA Level 1 and 2 qualifications. The "Naïve" models treat the post-birth TPU school enrollment variable as exogenous. The estimated marginal effects are 17.1 and 13.5 percentage-point increases in the probability of completing NCEA Level 1 and 2 qualifications, respectively, if the young women enrolled in a TPU rather than a non-TPU school post-birth. The $p$-values are better than a 0.1 percent in both cases. We suspect that these estimates suffer from simultaneous-equation bias, because this decision to enroll in a TPU school post-birth is partly a choice variable.

\footnotetext{
${ }^{18}$ Instrumental variables must be correlated with the regressor (TPU), but uncorrelated with the disturbance term. A valid instrument would be something that influences the propensity to enroll in a TPU school postbirth, but is unrelated to the unmeasured factors that influence the propensity to complete NCEA qualifications. We argue that distance to the nearest TPU governing school prior to conception meets these criteria.
} 
The IV probit models treat post-birth TPU school enrollment as endogenous. The estimated marginal effects are 28.4 and 20.0 percentage-point increases in the probability of completing NCEA Level 1 and 2 qualifications, respectively, from enrolling in a TPU school post-birth. The $p$-values are better than a 0.6 and 2.0 percent, respectively. These estimated marginal effects are considerably larger than those from the Naïve model, which suggests that young women who were more likely to enroll in TPUs after birth were generally less likely to complete NCEA qualifications than those who enrolled in non-TPU schools after birth. In other words, the presence of TPU governing schools tends to draw teen mothers with lower overall propensities to complete NCEA qualifications back to school. ${ }^{19}$

\section{Table 10: Marginal Effects for Teen Mothers of Post-Birth TPU School Enrollment on the Probabilities of Completing NCEA Qualifications}

\begin{tabular}{|c|c|c|c|c|}
\hline \multirow[b]{2}{*}{ Explanatory Variable } & \multicolumn{2}{|c|}{$\begin{array}{l}\text { Estimated effect on probability } \\
\text { of completing NCEA Level } 1 \\
\text { [95\% confidence interval] } \\
\text { and } p \text {-value }\end{array}$} & \multicolumn{2}{|c|}{$\begin{array}{c}\text { Estimated effect on probability } \\
\text { of completing NCEA Level } 2 \\
\text { [95\% confidence interval] } \\
\text { and } p \text {-value }\end{array}$} \\
\hline & $\begin{array}{l}\text { Naïve } \\
\text { Probit }\end{array}$ & $\begin{array}{l}\text { IV } \\
\text { Probit }\end{array}$ & $\begin{array}{l}\text { Naïve } \\
\text { Probit }\end{array}$ & $\begin{array}{l}\text { IV } \\
\text { Probit }\end{array}$ \\
\hline Enrolled post-birth in TPU school & $\begin{array}{c}0.171^{* * *} \\
{\left[\begin{array}{ll}0.117 & 0.226\end{array}\right]} \\
p=0.000\end{array}$ & $\begin{array}{c}0.284^{* * *} \\
{[0.0830 .485]} \\
p=0.006\end{array}$ & $\begin{array}{c}0.135^{* * *} \\
{[0.0900 .181]} \\
p=0.000\end{array}$ & $\begin{array}{c}0.200^{* *} \\
{\left[\begin{array}{cc}0.032 & 0.368\end{array}\right]} \\
p=0.020\end{array}$ \\
\hline F-statistic from first stage regression & --- & 10.05 & --- & 4.41 \\
\hline $\begin{array}{l}\text { Mean NCEA completion rates for } \\
\text { sample enrolled in TPU schools }\end{array}$ & \multicolumn{2}{|c|}{$\begin{array}{c}0.53 \\
n=720\end{array}$} & \multicolumn{2}{|c|}{$\begin{array}{c}0.40 \\
n=903\end{array}$} \\
\hline $\begin{array}{l}\text { Mean NCEA completion rates for } \\
\text { sample enrolled in non-TPU schools }\end{array}$ & \multicolumn{2}{|c|}{$\begin{array}{c}0.37 \\
n=801\end{array}$} & \multicolumn{2}{|c|}{$\begin{array}{c}0.27 \\
n=1,008\end{array}$} \\
\hline$N$ & \multicolumn{2}{|c|}{1,521} & \multicolumn{2}{|c|}{1,911} \\
\hline
\end{tabular}

Notes; ${ }^{*} p<0.10,{ }^{* *} p<0.05,{ }^{* * *} p<0.01$. Instruments are distance (in kilometers) to the nearest TPU governing school at or prior to conception and enrollment in a TPU school at or prior to conception. This table only reports the key findings from this analysis. A full set of regression results can be found in Tables 10A and 10B in the Appendix.

As noted, the fact that the estimated effects in the IV regressions are larger than those in the Naïve estimates suggest that those young women who self-select into TPUs are less likely to complete NCEA qualifications. To test this, we re-estimate model (4) for young women who did not give birth but were enrolled in school at age 14. For this estimation, TPU is an indicator

\footnotetext{
${ }^{19}$ We need to be cautious in interpreting these IV results. It is well known that this IV estimation produces Local Average Treatment Effects (LATEs) where greater weight in computing these estimates is placed on individuals whose treatment is most influenced by these instrumental variables. For this reason, it's possible that the LATEs could easily exceed Average Treatment Effects for the general population.
} 
variable which reflects whether the young woman was enrolled in a TPU or non-TPU school at age 14. Table 11 presents these results. We are not able to control for the same extensive set of covariates, but we find that young women enrolled in TPU governing schools were less likely to achieve any NCEA qualifications by the end of the year in which they turned 19 compared to young women enrolled in other schools. This is not an unexpected resulted because we know that TPUs are generally linked to schools and located in places where there are higher teen pregnancy rates. It does, however, confirm that our interpretation that TPUs generally attract young women with lower overall propensities to complete school qualifications is likely to be correct.

Table 11: Marginal Effects for Women Who Did Not Have a Teen Birth of TPU School Enrollment at Age 14 on the Probabilities of Completing NCEA Qualifications

\begin{tabular}{|c|c|c|}
\hline Explanatory Variable & $\begin{array}{l}\text { Estimated effect on probability } \\
\text { of completing NCEA Level } 1 \\
\text { [95\% confidence interval] } \\
\text { and } p \text {-value }\end{array}$ & $\begin{array}{c}\text { Estimated effect on probability } \\
\text { of completing NCEA Level } 2 \\
\text { [95\% confidence interval] } \\
\text { and } p \text {-value }\end{array}$ \\
\hline $\begin{array}{c}\text { TPU governing school enrolled at } \\
\text { age } 14\left(T P U_{\text {age } 14}\right)\end{array}$ & $\begin{array}{c}-0.001 \\
{\left[\begin{array}{cc}-0.009 & 0.006\end{array}\right]} \\
p=0.698\end{array}$ & $\begin{array}{c}-0.014^{* * *} \\
{[-0.024 \quad-0.003]} \\
p=0.009\end{array}$ \\
\hline$n$ & 77,826 & 77,826 \\
\hline
\end{tabular}

Notes; $* p<0.10, * * p<0.05, * * * p<0.01$. This table only reports the key findings from this analysis. A full set of regression results can be found in Table $11 \mathrm{~A}$ in the Appendix.

\section{$6 \quad$ Limitations}

There are a number of limitations that need to be considered in interpreting the results of this study. Data linking is probabilistic and some errors are inevitable. The data capture information collected or generated in the process of administering government services, and inevitably may embody measurement, reporting or recording errors that occur in those processes.

Data limitations result in some degree of imprecision in the estimation of true impacts. Most critically, we cannot observe whether a young mother was actually enrolled in a TPU, only whether she was enrolled in TPU governing school. We are also unable to measure the exact date at which NCEA Level 1 and 2 qualifications were attained, only the end of the calendar in which sufficient credits were received for these qualifications. In addition, in some cases young women who gave birth may not have gone on to parent their children, and given the data available to us we were unable to restrict the analysis to just to those young women who were 
engaged in parenting. Finally, given the confines of the data linkage our analysis fails to capture educational outcomes for young women who left the country through outward migration.

There are also limitations in the methods that we used since there may be unobserved selection, particularly on community characteristics, that may not have been adequately controlled for in our analysis. There is some censoring, but we did not want to drop birth cohorts from the analysis if possible. We test the robustness of the NCEA results by re-analysing for two subsamples that exclude cases affected by censoring by including only sample members whose conception date was after the date that they first appeared in the Ministry of Education data, and those in the 1992 and 1993 cohorts (who experienced no censoring). Our qualitative results were unaffected by these alternative specifications.

We examined particular birth cohorts and educational outcomes within a finite follow-up period. It may not be possible to generalise our findings to other birth cohorts, to outcomes at older ages, or to outcomes in other domains.

\section{$7 \quad$ Conclusions}

This evaluation finds that access to TPUs increased school enrollment rates and increased initial school qualifications of teenage mothers. The baseline school enrollment rate after birth for the teenage mothers studied was 35 percent. Those who had access to a TPU within 20 kilometers at or prior to conception were 3.9 percentage points more likely to enroll in a school after giving birth. Those who had immediate access to a TPU by virtue of being enrolled in a TPU school at or prior to conception were an additional 4.6 percentage points more likely to enroll post-birth. Among all teen mothers, TPU enrollment at or prior to conception had positive and significant effects on the probabilities of attaining NCEA qualifications. Among teen mothers who enrolled in school post-birth, TPU enrollment increased the probabilities of completing NCEA qualifications by 20 percentage points or more, once we controlled for endogeneity of TPU enrollment.

The findings provided in this report indicate that TPU services designed to meet the needs of teenage mothers can reduce the school enrollment and achievement gaps between teen mothers and young women who do not give birth. 


\section{References}

Baragwanath, S. (1997). The Education of Teenage Mothers in New Zealand: A Policy Vacuum and a Practical Example of Assistance. Social Policy Journal of New Zealand Issue 9.

Families Commission (2011) Teenage Pregnancy and Parenting: An Overview. Wellington: Families' Commission.

Fergusson, D. and L. Woodward (2000). Teenage pregnancy and female educational underachievement: A prospective study of a New Zealand birth cohort. Journal of Marriage and Family 62 (1): 147-161.

Harden, A., Brunton, G., Fletcher, A., Oakley, A., Burchett, H., Backhans, M. (2006) Young people, pregnancy and social exclusion: A systematic synthesis of research evidence to identify effective, appropriate and promising approaches for prevention and support. London: EPPI-Centre, Social Science Research Unit, Institute of Education, University of London.

Kearney, M. and Levine, P. (2014) Media influences on social outcomes: the impact of MTV's 16 and pregnant on teen childbearing, NBER Working Paper No. 19795.

Lachance, C., Burrus, B., Scott, A. (2012). Building an evidence base to inform interventions for pregnant and parenting adolescents: A call for rigorous evaluation. American Journal of Public Health. 102:1826-1832.

Pinzon, J., and Jones, V. (2012). Care of Adolescent Parents and their Children. American Academy of Pediatrics, 130 (6): 1-16.

Seitz, V., and Apfel, N. (1999). Effective interventions for adolescent mothers. Clinical Psychology: Science and Practice, 6 (1): 50-66.

Sedgh, G., Finer, L., Bankole,A. Eilers, M., and Singh, S. (2015). Adolescent pregnancy, birth and abortion rates across countries: levels and recent trends, Journal of Adolescent Health, 56: 223-230.

Woodward, L. and D. Fergusson (1999). Early conduct problems and later risk of teenage pregnancy in girls. Development and Psychopathology 11(01): 127-141. 


\section{Appendix - Supplementary Tables and Figures}

Table 1A: Teen Parent Units in Operation $(n=23)$

\begin{tabular}{|c|c|}
\hline Teen Parent Unit Name & Governing School \\
\hline He Mataariki School for Teen Parents & Mangakahia Area School, Whangarei \\
\hline Connected Learning Centre & Tangaroa College, Auckland \\
\hline He Wero o nga Wahine & Henderson High School, Auckland \\
\hline Eden Campus & Auckland Girls' Grammar, Auckland \\
\hline Clendon Teen Parent Unit (Taonga Education Centre) & James Cook High School, Auckland \\
\hline Hamilton's Fraser High School TPU & Fraser High School, Hamilton \\
\hline Pa Harakeke Teen Parent Unit & Tokoroa High School, Tokoroa \\
\hline Rotorua School for Young Parents & Rotorua Girls' High School, Rotorua \\
\hline Te Whakatipuranga & Otumoetai College, Tauranga \\
\hline $\begin{array}{l}\text { Te Tari Ako Matua Taiohi Teen Parent Education } \\
\text { Centre }\end{array}$ & Tarawera High School, Kawerau \\
\hline Hawke's Bay School for Teenage Parents & William Colenso College, Napier \\
\hline Te Whare Whai Hua Teenage Parent Centre & Lytton High School, Gisborne \\
\hline Whaimana Ako Second Chance Taranaki & Stratford High School, Stratford \\
\hline Whakatipuria Teen Parent Unit & Freyberg High School, Palmerston North \\
\hline He Whare Poipoia & Waiopehu College, Levin \\
\hline Titiro Whakamua & Heretaunga College, Upper Hutt \\
\hline He Huarahi Tamariki & $\begin{array}{l}\text { Wellington East Girls' College, Wellington (TPU } \\
\text { located in Linden next to Linden School, Tawa). }\end{array}$ \\
\hline Wairarapa Teen Parent Unit & Makoura College, Masterton \\
\hline Nelson Teen Parent Unit & $\begin{array}{l}\text { Nelson College for Girls, Nelson (TPU located on } \\
\text { Auckland Point School site, Nelson) }\end{array}$ \\
\hline Karanga Mai Young Parents College & Kaiapoi High School, Kaiapoi \\
\hline Kimihia Parents' College & Linwood College, Christchurch \\
\hline Murihiku Young Parents Learning Centre & James Hargest College, Invercargill \\
\hline
\end{tabular}


Figure 1A: Distribution of TPUs across the country

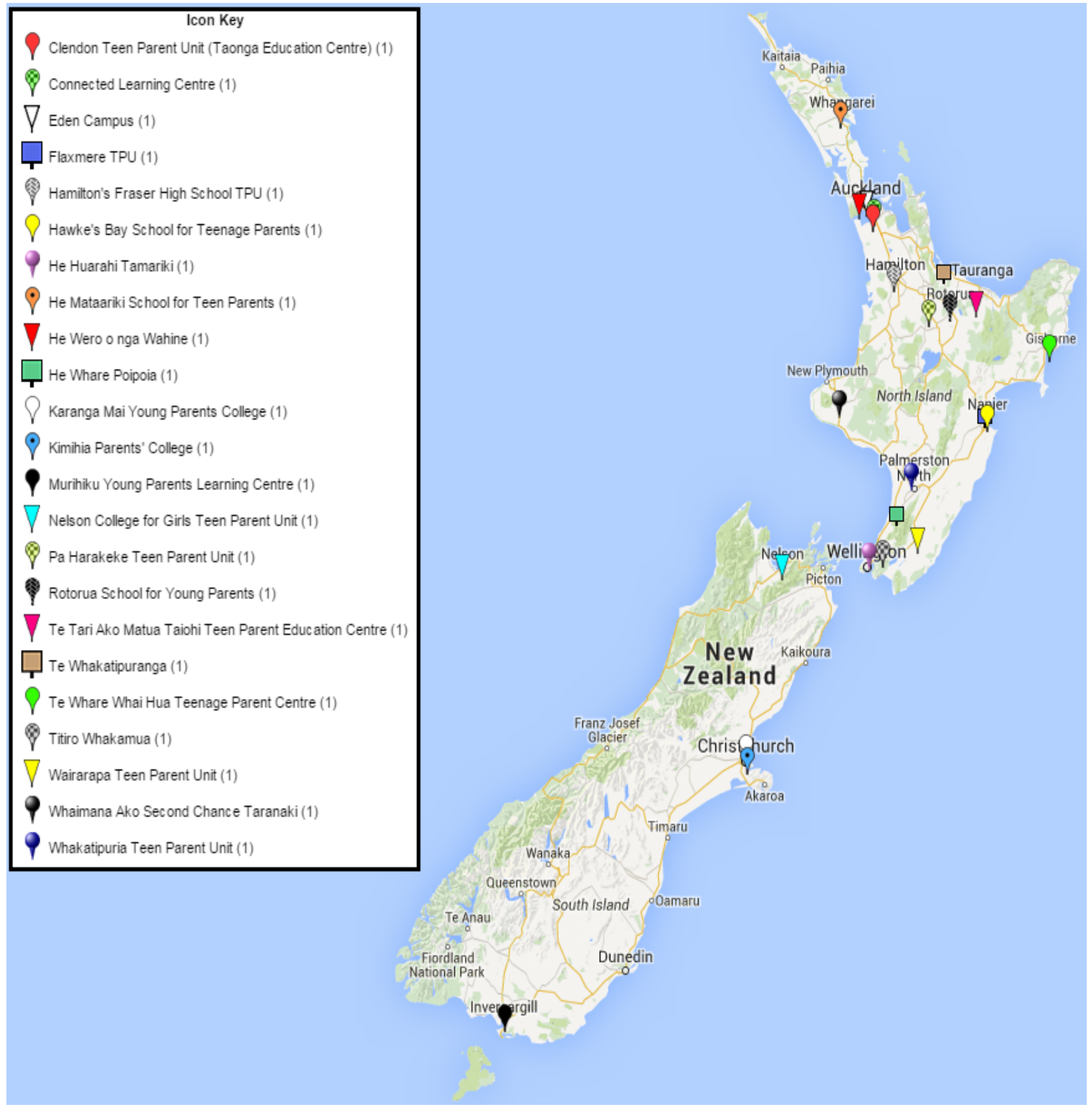


Figure 2A: Historical teen fertility rates in New Zealand

60

45

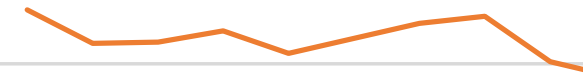

15

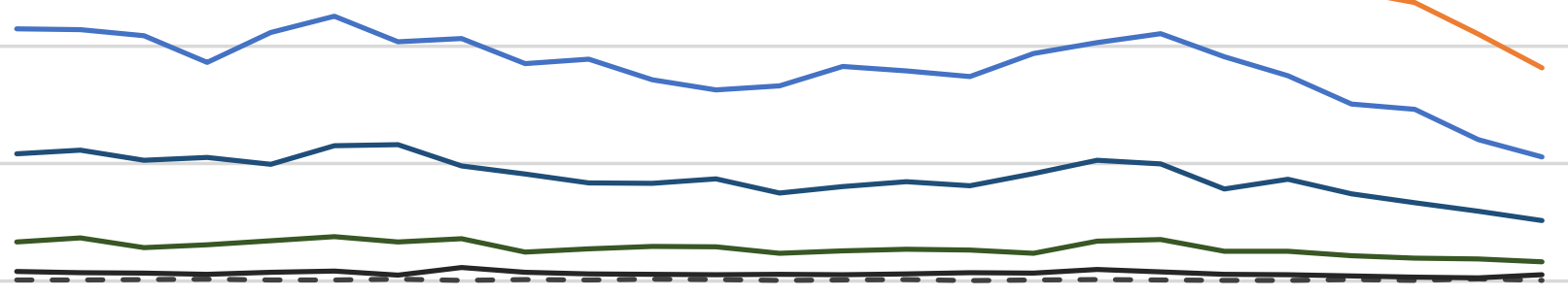

1990199119921993199419951996199719981999200020012002200320042005200620072008200920102011201220132014

$-\boldsymbol{-}-13$ years $\longrightarrow$ years 15 years $\longrightarrow 16$ years $\longrightarrow 18$ years $\longrightarrow$

Source: Statistics New Zealand. Notes: Live births per 1,000 mean estimated female population in each age group. 
Table 7A: Maximum Likelihood Probit Results Marginal Effects for Teen Mothers on the Probability of Post-Birth School Enrollment

\begin{tabular}{|c|c|}
\hline Explanatory Variables & $\begin{array}{l}\text { Mean of Estimated } \\
\text { Marginal Effects }\end{array}$ \\
\hline $\begin{array}{l}\text { TPU school }<20 \mathrm{~km}\left(T P U_{20 K M}\right) \\
\text { at or prior to conception }\end{array}$ & $\begin{array}{c}\mathbf{0 . 0 3 9}^{* *} \\
(\mathbf{0 . 0 1 7})\end{array}$ \\
\hline $\begin{array}{l}\text { Enrolled in TPU school }\left(T P U_{P r e-B i r t h}\right) \\
\text { at or prior to conception }\end{array}$ & $\begin{array}{l}0.046^{* *} \\
(0.021)\end{array}$ \\
\hline European & $\begin{array}{l}0.050^{* *} \\
(0.021)\end{array}$ \\
\hline Maori & $\begin{array}{c}0.033 \\
(0.021)\end{array}$ \\
\hline Pacific & $\begin{array}{c}0.009 \\
(0.026)\end{array}$ \\
\hline Asian & $\begin{array}{c}0.096^{*} \\
(0.059) \\
\end{array}$ \\
\hline Other ethnicity & $\begin{array}{c}0.050 \\
(0.070)\end{array}$ \\
\hline 1992 birth cohort & $\begin{array}{l}-0.011 \\
(0.017) \\
\end{array}$ \\
\hline 1993 birth cohort & $\begin{array}{l}0.046^{* *} \\
(0.018)\end{array}$ \\
\hline 1994 birth cohort & $\begin{array}{l}0.239^{* * *} \\
(0.023)\end{array}$ \\
\hline Minor urban area & $\begin{array}{l}-0.001 \\
(0.021)\end{array}$ \\
\hline Secondary urban area & $\begin{array}{c}0.086 \\
(0.085) \\
\end{array}$ \\
\hline Rural area & $\begin{array}{l}-0.032 \\
(0.040) \\
\end{array}$ \\
\hline Rural/urban not applicable/missing & $\begin{array}{c}0.001 \\
(0.025)\end{array}$ \\
\hline $\begin{array}{l}\text { Ever placed in care of Child, Youth and } \\
\text { Family }\end{array}$ & $\begin{array}{c}0.013 \\
(0.021) \\
\end{array}$ \\
\hline Ever Youth Justice involvement & $\begin{array}{l}-0.031 \\
(0.020)\end{array}$ \\
\hline $\begin{array}{l}\text { Proportion of first five years mother as a } \\
\text { child on a benefit }\end{array}$ & $\begin{array}{c}0.010 \\
(0.022) \\
\end{array}$ \\
\hline School enrollment size/100 & $\begin{array}{l}-0.002 \\
(0.002) \\
\end{array}$ \\
\hline School deciles 3 or 4 & $\begin{array}{c}0.004 \\
(0.020)\end{array}$ \\
\hline School deciles 5 or 6 & $\begin{array}{l}0.047^{* *} \\
(0.022)\end{array}$ \\
\hline School deciles 7 or 8 & $\begin{array}{c}0.021 \\
(0.026) \\
\end{array}$ \\
\hline School deciles 9 or 10 & $\begin{array}{c}0.086^{* *} \\
(0.035)\end{array}$ \\
\hline
\end{tabular}


Table 7A Continued

\begin{tabular}{|c|c|}
\hline South Auckland MOE office & $\begin{array}{c}0.018 \\
(0.029)\end{array}$ \\
\hline Christchurch MOE office & $\begin{array}{l}0.116^{\text {*** }} \\
(0.033)\end{array}$ \\
\hline Dunedin MOE office & $\begin{array}{c}0.056 \\
(0.052)\end{array}$ \\
\hline Hamilton MOE office & $\begin{array}{c}0.067^{* *} \\
(0.028)\end{array}$ \\
\hline Invercargill MOE office & $\begin{array}{l}0.124^{\text {**** }} \\
(0.048)\end{array}$ \\
\hline Napier MOE office & $\begin{array}{l}0.114^{\text {*** }} \\
(0.032)\end{array}$ \\
\hline Nelson MOE office & $\begin{array}{l}-0.017 \\
(0.044)\end{array}$ \\
\hline Rotorua MOE office & $\begin{array}{l}0.113^{\text {*** }} \\
(0.030)\end{array}$ \\
\hline Wellington MOE office & $\begin{array}{l}0.158^{\text {*** }} \\
(0.029)\end{array}$ \\
\hline Whanganui MOE office & $\begin{array}{l}0.121^{\text {*** }} \\
(0.032)\end{array}$ \\
\hline Whangarei MOE office & $\begin{array}{c}0.079^{* *} \\
(0.036)\end{array}$ \\
\hline$n$ & 5,634 \\
\hline Log-likelihood function & $-3,551.17$ \\
\hline Likelihood-ratio $\chi^{2}$ statistic & 276.07 \\
\hline$p$-value $\chi^{2}$ test & 0.0000 \\
\hline Pseudo $R^{2}$ statistic & 0.0374 \\
\hline
\end{tabular}

Notes: These are the estimated marginal effects from the full regression. Standard errors in parentheses. See the notes at the bottom of Table 7 in the main body of this paper for more information on this estimation procedure.

**** Estimated partial derivative significantly different from zero at a $1 \%$ level using a $t$ test

** Estimated partial derivative significantly different from zero at a 5\% level using a $t$ test

* Estimated partial derivative significantly different from zero at a $10 \%$ level using a $t$ test 
Table 8A: Maximum Likelihood Probit Results Marginal Effects for Teen Mothers on the Probabilities of Completing NCEA Qualifications

\begin{tabular}{|c|c|c|}
\hline \multirow[b]{2}{*}{ Explanatory Variables } & \multicolumn{2}{|c|}{ Mean of Estimated Marginal Effects } \\
\hline & $\begin{array}{l}\text { NCEA } \\
\text { Level } 1\end{array}$ & $\begin{array}{l}\text { NCEA } \\
\text { Level } 2\end{array}$ \\
\hline $\begin{array}{l}\text { TPU school }<20 \mathrm{~km}\left(T P U_{20 K M}\right) \\
\text { at or prior to conception }\end{array}$ & $\begin{array}{l}-0.005 \\
(0.019)\end{array}$ & $\begin{array}{l}-0.002 \\
(0.015)\end{array}$ \\
\hline $\begin{array}{l}\left.\text { Enrolled in TPU school (TPU } U_{\text {Pre-Birth }}\right) \\
\text { at or prior to conception }\end{array}$ & $\begin{array}{c}0.043^{*} \\
(\mathbf{0 . 0 2 3 )}\end{array}$ & $\begin{array}{r}\mathbf{0 . 0 3 5}^{*} \\
(\mathbf{0 . 0 1 9 )}\end{array}$ \\
\hline European & $\begin{array}{l}0.058^{* *} \\
(0.024)\end{array}$ & $\begin{array}{c}0.026 \\
(0.019) \\
\end{array}$ \\
\hline Maori & $\begin{array}{c}0.006 \\
(0.023)\end{array}$ & $\begin{array}{l}-0.005 \\
(0.018)\end{array}$ \\
\hline Pacific & $\begin{array}{l}0.114^{* * *} \\
(0.032)\end{array}$ & $\begin{array}{l}0.072^{* * *} \\
(0.026)\end{array}$ \\
\hline Asian & $\begin{array}{l}-0.012 \\
(0.065) \\
\end{array}$ & $\begin{array}{c}0.041 \\
(0.054) \\
\end{array}$ \\
\hline Other ethnicity & $\begin{array}{l}0.232^{* * *} \\
(0.084)\end{array}$ & $\begin{array}{l}0.253^{* * *} \\
(0.078)\end{array}$ \\
\hline 1992 birth cohort & $\begin{array}{l}-0.002 \\
(0.019) \\
\end{array}$ & $\begin{array}{l}-0.024 \\
(0.015) \\
\end{array}$ \\
\hline 1993 birth cohort & $\begin{array}{c}0.007 \\
(0.021)\end{array}$ & $\begin{array}{c}0.014 \\
(0.016)\end{array}$ \\
\hline 1994 birth cohort & $\begin{array}{l}0.064^{* *} \\
(0.025)\end{array}$ & $\begin{array}{l}0.045^{* *} \\
(0.020)\end{array}$ \\
\hline Minor urban area & $\begin{array}{l}-0.023 \\
(0.023)\end{array}$ & $\begin{array}{l}-0.036^{* *} \\
(0.018)\end{array}$ \\
\hline Secondary urban area & $\begin{array}{l}-0.007 \\
(0.093)\end{array}$ & $\begin{array}{l}-0.035 \\
(0.071)\end{array}$ \\
\hline Rural area & $\begin{array}{l}-0.005 \\
(0.047) \\
\end{array}$ & $\begin{array}{c}0.003 \\
(0.037) \\
\end{array}$ \\
\hline Rural/urban not applicable/missing & $\begin{array}{c}0.008 \\
(0.027)\end{array}$ & $\begin{array}{c}0.021 \\
(0.023)\end{array}$ \\
\hline $\begin{array}{l}\text { Ever placed in care of Child, Youth and } \\
\text { Family }\end{array}$ & $\begin{array}{l}-0.060^{* * *} \\
(0.020)\end{array}$ & $\begin{array}{l}-0.052^{* * *} \\
(0.017)\end{array}$ \\
\hline Ever Youth Justice involvement & $\begin{array}{l}-0.119^{* * *} \\
(0.018)\end{array}$ & $\begin{array}{l}-0.125^{* * *} \\
(0.014)\end{array}$ \\
\hline $\begin{array}{l}\text { Proportion of first five years mother as a } \\
\text { child on a benefit }\end{array}$ & $\begin{array}{l}-0.053^{* *} \\
(0.024)\end{array}$ & $\begin{array}{l}-0.062^{* *} \\
(0.020)\end{array}$ \\
\hline School enrollment size/100 & $\begin{array}{l}-0.005^{* * *} \\
(0.002)\end{array}$ & $\begin{array}{l}-0.003^{* *} \\
(0.001)\end{array}$ \\
\hline School deciles 3 or 4 & $\begin{array}{c}0.023 \\
(0.022) \\
\end{array}$ & $\begin{array}{c}0.012 \\
(0.018) \\
\end{array}$ \\
\hline School deciles 5 or 6 & $\begin{array}{c}0.055^{* *} \\
(0.025) \\
\end{array}$ & $\begin{array}{l}0.056^{* * *} \\
(0.020)\end{array}$ \\
\hline School deciles 7 or 8 & $\begin{array}{l}0.084^{* * *} \\
(0.032)\end{array}$ & $\begin{array}{c}0.061^{\text {** }} \\
(0.025)\end{array}$ \\
\hline School deciles 9 or 10 & $\begin{array}{l}0.148^{* * *} \\
(0.045)\end{array}$ & $\begin{array}{l}0.155^{\text {**** }} \\
(0.037)\end{array}$ \\
\hline
\end{tabular}




\begin{tabular}{|c|c|c|}
\hline South Auckland MOE office & $\begin{array}{c}-0.042 \\
(0.030)\end{array}$ & $\begin{array}{l}-0.047^{* *} \\
(0.022)\end{array}$ \\
\hline Christchurch MOE office & $\begin{array}{l}-0.086^{* * *} \\
(0.029)\end{array}$ & $\begin{array}{l}-0.103^{\text {*** }} \\
(0.020)\end{array}$ \\
\hline Dunedin MOE office & $\begin{array}{l}-0.073 \\
(0.050)\end{array}$ & $\begin{array}{l}-0.048 \\
(0.037)\end{array}$ \\
\hline Hamilton MOE office & $\begin{array}{c}-0.029 \\
(0.028) \\
\end{array}$ & $\begin{array}{l}-0.025 \\
(0.022) \\
\end{array}$ \\
\hline Invercargill MOE office & $\begin{array}{c}-0.016 \\
(0.047)\end{array}$ & $\begin{array}{l}-0.059^{*} \\
(0.033)\end{array}$ \\
\hline Napier MOE office & $\begin{array}{c}0.045 \\
(0.035) \\
\end{array}$ & $\begin{array}{l}-0.014 \\
(0.026) \\
\end{array}$ \\
\hline Nelson MOE office & $\begin{array}{l}-0.098^{* * *} \\
(0.038)\end{array}$ & $\begin{array}{l}-0.118^{* * *} \\
(0.025)\end{array}$ \\
\hline Rotorua MOE office & $\begin{array}{l}-0.005 \\
(0.031)\end{array}$ & $\begin{array}{c}0.001 \\
(0.025)\end{array}$ \\
\hline Wellington MOE office & $\begin{array}{c}0.007 \\
(0.030) \\
\end{array}$ & $\begin{array}{l}-0.020 \\
(0.023) \\
\end{array}$ \\
\hline Whanganui MOE office & $\begin{array}{l}-0.030 \\
(0.032)\end{array}$ & $\begin{array}{l}-0.058^{\text {**** }} \\
(0.023)\end{array}$ \\
\hline Whangarei MOE office & $\begin{array}{c}-0.029 \\
(0.036)\end{array}$ & $\begin{array}{l}-0.017 \\
(0.029)\end{array}$ \\
\hline$N$ & 3,849 & 4,914 \\
\hline Log-likelihood function & $-2,175.45$ & $-2,426.25$ \\
\hline Likelihood-ratio $\chi^{2}$ statistic & 182.36 & 246.12 \\
\hline$p$-value $\chi^{2}$ test & 0.000 & 0.000 \\
\hline Pseudo $R^{2}$ statistic & 0.0402 & 0.0483 \\
\hline
\end{tabular}

Notes: These are the estimated marginal effects from the full regression. Standard errors in parentheses. See the notes at the bottom of Table 8 in the main body of this paper for more information on this estimation procedure.

*** Estimated partial derivative significantly different from zero at a $1 \%$ level using a $t$ test

** Estimated partial derivative significantly different from zero at a 5\% level using a $t$ test

* Estimated partial derivative significantly different from zero at a $10 \%$ level using a $t$ test 
Table 9A: Maximum Likelihood Probit Results Marginal Effects for all Young Women of TPU School Enrollment at Age of 14 on the Probability of a Teen Birth

\begin{tabular}{|c|c|}
\hline Explanatory Variables & $\begin{array}{c}\text { Mean of Estimated } \\
\text { Marginal Effects }\end{array}$ \\
\hline $\begin{array}{l}\text { Enrolled in TPU school at age } 14 \\
\left(T P U_{a g e=14}\right)\end{array}$ & $\begin{array}{c}\mathbf{0 . 0 0 2} \\
(\mathbf{0 . 0 0 2}) \\
\end{array}$ \\
\hline European & $\begin{array}{l}-0.005^{* * *} \\
(0.002)\end{array}$ \\
\hline Maori & $\begin{array}{l}0.031^{* * *} \\
(0.003)\end{array}$ \\
\hline Pacific & $\begin{array}{c}0.003 \\
(0.002) \\
\end{array}$ \\
\hline Asian & $\begin{array}{l}-0.021^{* * *} \\
(0.001)\end{array}$ \\
\hline Other ethnicity & $\begin{array}{l}-0.012^{* * *} \\
(0.003)\end{array}$ \\
\hline 1992 birth cohort & $\begin{array}{l}-0.004^{* * *} \\
(0.001)\end{array}$ \\
\hline 1993 birth cohort & $\begin{array}{l}-0.008^{* * *} \\
(0.001)\end{array}$ \\
\hline 1994 birth cohort & $\begin{array}{l}-0.022^{* * *} \\
(0.001)\end{array}$ \\
\hline Minor urban area & $\begin{array}{l}-0.000 \\
(0.002) \\
\end{array}$ \\
\hline Secondary urban area & $\begin{array}{l}-0.012^{*} \\
(0.007)\end{array}$ \\
\hline Rural area & $\begin{array}{l}-0.004 \\
(0.003) \\
\end{array}$ \\
\hline Rural/urban not applicable/missing & $\begin{array}{c}0.002 \\
(0.002)\end{array}$ \\
\hline $\begin{array}{l}\text { Ever placed in care of Child, Youth and } \\
\text { Family }\end{array}$ & $\begin{array}{l}0.039^{* * *} \\
(0.005)\end{array}$ \\
\hline Ever Youth Justice involvement & $\begin{array}{l}0.074^{* * *} \\
(0.008)\end{array}$ \\
\hline $\begin{array}{l}\text { Proportion of first five years mother as a } \\
\text { child on a benefit }\end{array}$ & $\begin{array}{l}0.040^{* * *} \\
(0.002)\end{array}$ \\
\hline School enrollment size/100 & $\begin{array}{c}0.000^{*} \\
(0.000) \\
\end{array}$ \\
\hline School deciles 3 or 4 & $\begin{array}{l}-0.004^{* * *} \\
(0.002)\end{array}$ \\
\hline School deciles 5 or 6 & $\begin{array}{l}-0.009^{* * *} \\
(0.002)\end{array}$ \\
\hline School deciles 7 or 8 & $\begin{array}{l}-0.015^{* *} \\
(0.001)\end{array}$ \\
\hline School deciles 9 or 10 & $\begin{array}{l}-0.028^{* * *} \\
(0.001)\end{array}$ \\
\hline
\end{tabular}


Table 9A Continued

\begin{tabular}{|c|c|}
\hline South Auckland MOE office & $\begin{array}{c}0.004^{*} \\
(0.002) \\
\end{array}$ \\
\hline Christchurch MOE office & $\begin{array}{c}-0.001 \\
(0.002)\end{array}$ \\
\hline Dunedin MOE office & $\begin{array}{c}-0.001 \\
(0.003)\end{array}$ \\
\hline Hamilton MOE office & $\begin{array}{c}0.006^{* *} \\
(0.002)\end{array}$ \\
\hline Invercargill MOE office & $\begin{array}{c}0.009^{* *} \\
(0.004)\end{array}$ \\
\hline Napier MOE office & $\begin{array}{c}-0.001 \\
(0.002) \\
\end{array}$ \\
\hline Nelson MOE office & $\begin{array}{c}-0.003 \\
(0.003)\end{array}$ \\
\hline Rotorua MOE office & $\begin{array}{c}-0.002 \\
(0.002)\end{array}$ \\
\hline Wellington MOE office & $\begin{array}{l}0.007^{\text {*** }} \\
(0.002)\end{array}$ \\
\hline Whanganui MOE office & $\begin{array}{c}0.008^{\text {*** }} \\
(0.003)\end{array}$ \\
\hline Whangarei MOE office & $\begin{array}{c}0.000 \\
(0.003)\end{array}$ \\
\hline$n$ & 81,129 \\
\hline Log-likelihood function & $-11,962.6$ \\
\hline Likelihood-ratio $\chi^{2}$ statistic & $3,685.3$ \\
\hline$p$-value $\chi^{2}$ test & 0.0000 \\
\hline Pseudo $R^{2}$ statistic & 0.1335 \\
\hline
\end{tabular}

Notes: These are the estimated marginal effects from the full regression. Standard errors in parentheses. See the notes at the bottom of Table 9 in the main body of this paper for more information on this estimation procedure.

*** Estimated partial derivative significantly different from zero at a $1 \%$ level using a $t$ test

** Estimated partial derivative significantly different from zero at a 5\% level using a $t$ test

* Estimated partial derivative significantly different from zero at a $10 \%$ level using a $t$ test 
Table 10A: Maximum Likelihood Probit Results Marginal Effects for Teen Mothers of Post-Birth TPU School Enrollment on the Probabilities of Completing NCEA Qualifications

\begin{tabular}{|c|c|c|}
\hline \multirow[b]{2}{*}{ Explanatory Variables } & \multicolumn{2}{|c|}{ Mean of Estimated Marginal Effects } \\
\hline & Naïve Probit & IV Probit \\
\hline Enrolled in TPU school post-birth & $\begin{array}{c}0.171^{* * *} \\
(0.028)\end{array}$ & $\begin{array}{l}0.284^{* * *} \\
(0.103)\end{array}$ \\
\hline European & $\begin{array}{l}0.102^{* *} \\
(0.043)\end{array}$ & $\begin{array}{l}0.104^{* *} \\
(0.042)\end{array}$ \\
\hline Maori & $\begin{array}{c}0.008 \\
(0.042)\end{array}$ & $\begin{array}{c}0.005 \\
(0.042)\end{array}$ \\
\hline Pacific & $\begin{array}{c}0.104^{*} \\
(0.054)\end{array}$ & $\begin{array}{c}0.085 \\
(0.056) \\
\end{array}$ \\
\hline Asian & $\begin{array}{l}-0.109 \\
(0.107) \\
\end{array}$ & $\begin{array}{l}-0.119 \\
(0.105) \\
\end{array}$ \\
\hline Other ethnicity & $\begin{array}{l}0.440^{* * *} \\
(0.090)\end{array}$ & $\begin{array}{l}0.436^{\text {*** }} \\
(0.091)\end{array}$ \\
\hline 1992 birth cohort & $\begin{array}{l}-0.034 \\
(0.037) \\
\end{array}$ & $\begin{array}{l}-0.029 \\
(0.038) \\
\end{array}$ \\
\hline 1993 birth cohort & $\begin{array}{c}-0.051 \\
(0.037) \\
\end{array}$ & $\begin{array}{l}-0.049 \\
(0.037) \\
\end{array}$ \\
\hline 1994 birth cohort & $\begin{array}{l}-0.040 \\
(0.040) \\
\end{array}$ & $\begin{array}{l}-0.042 \\
(0.040) \\
\end{array}$ \\
\hline Minor urban area & $\begin{array}{c}0.022 \\
(0.042) \\
\end{array}$ & $\begin{array}{c}0.052 \\
(0.050) \\
\end{array}$ \\
\hline Secondary urban area & $\begin{array}{l}-0.045 \\
(0.164)\end{array}$ & $\begin{array}{c}0.013 \\
(0.176)\end{array}$ \\
\hline Rural area & $\begin{array}{c}0.168^{*} \\
(0.086) \\
\end{array}$ & $\begin{array}{c}0.187^{* *} \\
(0.086)\end{array}$ \\
\hline Rural/urban not applicable/missing & $\begin{array}{c}0.043 \\
(0.048)\end{array}$ & $\begin{array}{c}0.064 \\
(0.052)\end{array}$ \\
\hline $\begin{array}{l}\text { Ever placed in care of Child, Youth and } \\
\text { Family }\end{array}$ & $\begin{array}{l}-0.116^{* * *} \\
(0.038)\end{array}$ & $\begin{array}{l}-0.117^{* * *} \\
(0.038)\end{array}$ \\
\hline Ever Youth Justice involvement & $\begin{array}{l}-0.195^{* * *} \\
(0.036)\end{array}$ & $\begin{array}{l}-0.195^{* * *} \\
(0.036)\end{array}$ \\
\hline $\begin{array}{l}\text { Proportion of first five years mother as a } \\
\text { child on a benefit }\end{array}$ & $\begin{array}{l}-0.038 \\
(0.045) \\
\end{array}$ & $\begin{array}{l}-0.038 \\
(0.044) \\
\end{array}$ \\
\hline School enrollment size/100 & $\begin{array}{l}-0.005 \\
(0.003)\end{array}$ & $\begin{array}{l}-0.006 \\
(0.003)\end{array}$ \\
\hline School deciles 3 or 4 & $\begin{array}{c}0.023 \\
(0.039) \\
\end{array}$ & $\begin{array}{c}0.023 \\
(0.039) \\
\end{array}$ \\
\hline School deciles 5 or 6 & $\begin{array}{c}0.039 \\
(0.043)\end{array}$ & $\begin{array}{c}0.033 \\
(0.043)\end{array}$ \\
\hline School deciles 7 or 8 & $\begin{array}{c}0.088^{*} \\
(0.052)\end{array}$ & $\begin{array}{c}0.089^{*} \\
(0.052)\end{array}$ \\
\hline School deciles 9 or 10 & $\begin{array}{l}0.158^{* *} \\
(0.067)\end{array}$ & $\begin{array}{l}0.156^{* *} \\
(0.067)\end{array}$ \\
\hline
\end{tabular}


Table 10A Continued

\begin{tabular}{|c|c|c|}
\hline South Auckland MOE office & $\begin{array}{c}-0.067 \\
(0.059)\end{array}$ & $\begin{array}{c}-0.048 \\
(0.062)\end{array}$ \\
\hline Christchurch MOE office & $\begin{array}{l}-0.177^{\text {*** }} \\
(0.053)\end{array}$ & $\begin{array}{l}-0.195^{\text {**** }} \\
(0.054)\end{array}$ \\
\hline Dunedin MOE office & $\begin{array}{c}0.015 \\
(0.116)\end{array}$ & $\begin{array}{c}0.043 \\
(0.119)\end{array}$ \\
\hline Hamilton MOE office & $\begin{array}{c}-0.083 \\
(0.052) \\
\end{array}$ & $\begin{array}{c}-0.086 \\
(0.052) \\
\end{array}$ \\
\hline Invercargill MOE office & $\begin{array}{l}-0.108 \\
(0.082)\end{array}$ & $\begin{array}{l}-0.132 \\
(0.082)\end{array}$ \\
\hline Napier MOE office & $\begin{array}{l}-0.012 \\
(0.060)\end{array}$ & $\begin{array}{l}-0.047 \\
(0.067)\end{array}$ \\
\hline Nelson MOE office & $\begin{array}{c}-0.095 \\
(0.088)\end{array}$ & $\begin{array}{c}-0.066 \\
(0.094)\end{array}$ \\
\hline Rotorua MOE office & $\begin{array}{l}-0.029 \\
(0.056)\end{array}$ & $\begin{array}{c}-0.047 \\
(0.058)\end{array}$ \\
\hline Wellington MOE office & $\begin{array}{c}-0.024 \\
(0.054)\end{array}$ & $\begin{array}{c}-0.047 \\
(0.057)\end{array}$ \\
\hline Whanganui MOE office & $\begin{array}{c}-0.071 \\
(0.058)\end{array}$ & $\begin{array}{c}-0.073 \\
(0.058)\end{array}$ \\
\hline Whangarei MOE office & $\begin{array}{c}-0.041 \\
(0.072)\end{array}$ & $\begin{array}{c}-0.051 \\
(0.072)\end{array}$ \\
\hline$n$ & 1,521 & 1,521 \\
\hline Log-likelihood function & -965.72 & $-1,912.80$ \\
\hline Likelihood-ratio $\chi^{2}$ statistic & 155.31 & 122.55 \\
\hline$p$-value $\chi^{2}$ test & 0.0000 & 0.0000 \\
\hline Pseudo $R^{2}$ statistic & 0.0744 & --- \\
\hline
\end{tabular}

Notes: Full sets of regression results. See the notes at the bottom of Table 10 in the main body of this report for more information on these estimation procedures. The last two sets of regression results are from the second stage of these Instrumental Variable procedures. The first-stage results are available from the authors upon request. Instrumental variables are 'TPU school $<20 \mathrm{~km}$ at or prior to conception' and 'enrolled in TPU school at or prior to conception'.

${ }^{* * *}$ Estimated effect significantly different from zero at a $1 \%$ level using a $t$ test

** Estimated effect significantly different from zero at a 5\% level using a $t$ test

* Estimated effect significantly different from zero at a $10 \%$ level using a $t$ test 
Table 10B: Maximum Likelihood Probit Results

Estimated Effects on Probability of Completing NCEA Level 2 Qualifications Young Teen Mothers who Enrolled Post-Birth

\begin{tabular}{|c|c|c|}
\hline \multirow[b]{2}{*}{ Explanatory Variables } & \multicolumn{2}{|c|}{ Mean of Estimated Marginal Effects } \\
\hline & Naïve Probit & IV Probit \\
\hline Enrolled in TPU school post-birth & $\begin{array}{c}0.135^{* * *} \\
(0.023)\end{array}$ & $\begin{array}{c}0.200^{* *} \\
(0.086) \\
\end{array}$ \\
\hline European & $\begin{array}{c}0.055 \\
(0.035) \\
\end{array}$ & $\begin{array}{c}0.055 \\
(0.035) \\
\end{array}$ \\
\hline Maori & $\begin{array}{c}0.015 \\
(0.034) \\
\end{array}$ & $\begin{array}{c}0.013 \\
(0.034) \\
\end{array}$ \\
\hline Pacific & $\begin{array}{c}0.073 \\
(0.045) \\
\end{array}$ & $\begin{array}{c}0.063 \\
(0.047) \\
\end{array}$ \\
\hline Asian & $\begin{array}{c}0.086 \\
(0.093) \\
\end{array}$ & $\begin{array}{c}0.082 \\
(0.093)\end{array}$ \\
\hline Other ethnicity & $\begin{array}{l}0.417^{* * *} \\
(0.107)\end{array}$ & $\begin{array}{l}0.418^{* * *} \\
(0.106)\end{array}$ \\
\hline 1992 birth cohort & $\begin{array}{l}-0.070^{* *} \\
(0.029)\end{array}$ & $\begin{array}{l}-0.068^{* *} \\
(0.029) \\
\end{array}$ \\
\hline 1993 birth cohort & $\begin{array}{l}-0.046 \\
(0.030) \\
\end{array}$ & $\begin{array}{l}-0.046 \\
(0.030) \\
\end{array}$ \\
\hline 1994 birth cohort & $\begin{array}{l}-0.052 \\
(0.032) \\
\end{array}$ & $\begin{array}{l}-0.054 \\
(0.032) \\
\end{array}$ \\
\hline Minor urban area & $\begin{array}{l}-0.002 \\
(0.034) \\
\end{array}$ & $\begin{array}{c}0.016 \\
(0.042) \\
\end{array}$ \\
\hline Secondary urban area & $\begin{array}{l}-0.058 \\
(0.145) \\
\end{array}$ & $\begin{array}{l}-0.026 \\
(0.159) \\
\end{array}$ \\
\hline Rural area & $\begin{array}{c}0.131^{*} \\
(0.074)\end{array}$ & $\begin{array}{c}0.145^{*} \\
(0.077)\end{array}$ \\
\hline Rural/urban not applicable/missing & $\begin{array}{c}0.051 \\
(0.041)\end{array}$ & $\begin{array}{c}0.063 \\
(0.044)\end{array}$ \\
\hline $\begin{array}{l}\text { Ever placed in care of Child, Youth and } \\
\text { Family }\end{array}$ & $\begin{array}{l}-0.062^{*} \\
(0.034)\end{array}$ & $\begin{array}{l}-0.063^{*} \\
(0.034) \\
\end{array}$ \\
\hline Ever Youth Justice involvement & $\begin{array}{l}-0.229^{* * *} \\
(0.026)\end{array}$ & $\begin{array}{l}-0.230^{* * *} \\
(0.026)\end{array}$ \\
\hline $\begin{array}{l}\text { Proportion of first five years mother as a } \\
\text { child on a benefit }\end{array}$ & $\begin{array}{l}-0.020 \\
(0.038)\end{array}$ & $\begin{array}{l}-0.019 \\
(0.038)\end{array}$ \\
\hline School enrollment size/100 & $\begin{array}{l}-0.005 \\
(0.003)\end{array}$ & $\begin{array}{l}-0.006^{* *} \\
(0.003)\end{array}$ \\
\hline School deciles 3 or 4 & $\begin{array}{c}0.040 \\
(0.034) \\
\end{array}$ & $\begin{array}{c}0.040 \\
(0.033) \\
\end{array}$ \\
\hline School deciles 5 or 6 & $\begin{array}{c}0.056 \\
(0.037) \\
\end{array}$ & $\begin{array}{c}0.053 \\
(0.037) \\
\end{array}$ \\
\hline School deciles 7 or 8 & $\begin{array}{c}0.074^{*} \\
(0.045) \\
\end{array}$ & $\begin{array}{r}0.077^{*} \\
(0.045) \\
\end{array}$ \\
\hline School deciles 9 or 10 & $\begin{array}{l}0.163^{* * *} \\
(0.059)\end{array}$ & $\begin{array}{l}0.162^{\text {*** }} \\
(0.059)\end{array}$ \\
\hline
\end{tabular}


Table 10B Continued

\begin{tabular}{|c|c|c|}
\hline South Auckland MOE office & $\begin{array}{c}-0.069 \\
(0.046)\end{array}$ & $\begin{array}{c}-0.059 \\
(0.048)\end{array}$ \\
\hline Christchurch MOE office & $\begin{array}{l}-0.140^{* * *} \\
(0.040)\end{array}$ & $\begin{array}{l}-0.148^{* * *} \\
(0.041)\end{array}$ \\
\hline Dunedin MOE office & $\begin{array}{l}-0.070 \\
(0.074)\end{array}$ & $\begin{array}{c}-0.055 \\
(0.079)\end{array}$ \\
\hline Hamilton MOE office & $\begin{array}{c}-0.055 \\
(0.043) \\
\end{array}$ & $\begin{array}{c}-0.056 \\
(0.042) \\
\end{array}$ \\
\hline Invercargill MOE office & $\begin{array}{l}-0.117^{* *} \\
(0.059)\end{array}$ & $\begin{array}{l}-0.127^{* *} \\
(0.059)\end{array}$ \\
\hline Napier MOE office & $\begin{array}{c}-0.056 \\
(0.047)\end{array}$ & $\begin{array}{c}-0.074 \\
(0.051)\end{array}$ \\
\hline Nelson MOE office & $\begin{array}{l}-0.153^{* *} \\
(0.061)\end{array}$ & $\begin{array}{l}-0.143^{* *} \\
(0.064)\end{array}$ \\
\hline Rotorua MOE office & $\begin{array}{c}0.015 \\
(0.047)\end{array}$ & $\begin{array}{c}0.005 \\
(0.049)\end{array}$ \\
\hline Wellington MOE office & $\begin{array}{c}-0.061 \\
(0.042)\end{array}$ & $\begin{array}{c}-0.073 \\
(0.044)\end{array}$ \\
\hline Whanganui MOE office & $\begin{array}{l}-0.059 \\
(0.046)\end{array}$ & $\begin{array}{l}-0.060 \\
(0.046)\end{array}$ \\
\hline Whangarei MOE office & $\begin{array}{l}-0.012 \\
(0.057)\end{array}$ & $\begin{array}{c}-0.020 \\
(0.057)\end{array}$ \\
\hline$n$ & 1,914 & 1,914 \\
\hline Log-likelihood function & $-1,123.64$ & $-2,307.51$ \\
\hline Likelihood-ratio $\chi^{2}$ statistic & 175.83 & 132.60 \\
\hline$p$-value $\chi^{2}$ test & 0.0000 & 0.0000 \\
\hline Pseudo $R^{2}$ statistic & 0.0726 & --- \\
\hline
\end{tabular}

Notes: Full sets of regression results. See the notes at the bottom of Table 10 in the main body of this report for more information on these estimation procedures. The last two sets of regression results are from the second stage of these Instrumental Variable procedures. The first-stage results are available from the authors upon request. Instrumental variables are 'TPU school $<20 \mathrm{~km}$ at or prior to conception' and 'enrolled in TPU school at or prior to conception'.

${ }^{* * *}$ Estimated effect significantly different from zero at a $1 \%$ level using a $t$ test

** Estimated effect significantly different from zero at a 5\% level using a $t$ test

* Estimated effect significantly different from zero at a $10 \%$ level using a $t$ test 
Table 11A: Maximum Likelihood Probit Results

Marginal Effects for Women Who Did Not Have a Teen Birth of TPU School Enrollment at Age 14 on the Probabilities of Completing NCEA Qualifications

\begin{tabular}{|c|c|c|}
\hline & \multicolumn{2}{|c|}{ Mean of Estimated Marginal Effects } \\
\hline & $\begin{array}{l}\text { NCEA } \\
\text { Level } 1 \\
\end{array}$ & $\begin{array}{l}\text { NCEA } \\
\text { Level } 2 \\
\end{array}$ \\
\hline $\begin{array}{l}\text { Enrolled in TPU school at age } 14 \\
\left(T P U_{a g e=14}\right)\end{array}$ & $\begin{array}{l}-0.001 \\
(0.004)\end{array}$ & $\begin{array}{l}-0.014^{* * *} \\
(0.005)\end{array}$ \\
\hline European & $\begin{array}{l}0.042^{* * * *} \\
(0.004)\end{array}$ & $\begin{array}{l}0.052^{* * * *} \\
(0.006)\end{array}$ \\
\hline Maori & $\begin{array}{l}-0.045^{* * *} \\
(0.005)\end{array}$ & $\begin{array}{l}-0.083^{* * * *} \\
(0.006)\end{array}$ \\
\hline Pacific & $\begin{array}{l}0.017^{* * *} \\
(0.004)\end{array}$ & $\begin{array}{l}0.025^{* * *} \\
(0.006)\end{array}$ \\
\hline Asian & $\begin{array}{l}-0.001 \\
(0.005)\end{array}$ & $\begin{array}{l}0.019^{* * * *} \\
(0.006)\end{array}$ \\
\hline Other ethnicity & $\begin{array}{c}0.002 \\
(0.008) \\
\end{array}$ & $\begin{array}{c}0.015 \\
(0.010) \\
\end{array}$ \\
\hline 1992 birth cohort & $\begin{array}{c}0.001 \\
(0.003) \\
\end{array}$ & $\begin{array}{l}0.008^{* *} \\
(0.004)\end{array}$ \\
\hline 1993 birth cohort & $\begin{array}{l}0.013^{* * *} \\
(0.003)\end{array}$ & $\begin{array}{l}0.029^{* * *} \\
(0.004)\end{array}$ \\
\hline 1994 birth cohort & $\begin{array}{l}0.022^{* * *} \\
(0.003)\end{array}$ & $\begin{array}{l}0.041^{* * *} \\
(0.004)\end{array}$ \\
\hline Minor urban area & $\begin{array}{l}0.007^{* *} \\
(0.003)\end{array}$ & $\begin{array}{c}0.000 \\
(0.005)\end{array}$ \\
\hline Secondary urban area & $\begin{array}{l}-0.073^{* * *} \\
(0.026)\end{array}$ & $\begin{array}{l}-0.025 \\
(0.028)\end{array}$ \\
\hline Rural area & $\begin{array}{l}0.023^{* * *} \\
(0.005)\end{array}$ & $\begin{array}{c}0.012 \\
(0.008)\end{array}$ \\
\hline Rural/urban not applicable/missing & $\begin{array}{l}-0.002 \\
(0.004) \\
\end{array}$ & $\begin{array}{l}-0.003 \\
(0.005) \\
\end{array}$ \\
\hline $\begin{array}{l}\text { Ever placed in Child, Youth and Family } \\
\text { care }\end{array}$ & $\begin{array}{l}-0.134^{* * *} \\
(0.012)\end{array}$ & $\begin{array}{l}-0.190^{* * *} \\
(0.014)\end{array}$ \\
\hline Ever Youth Justice involvement & $\begin{array}{l}-0.224^{* * *} \\
(0.016)\end{array}$ & $\begin{array}{l}-0.298^{* * *} \\
(0.018)\end{array}$ \\
\hline $\begin{array}{l}\text { Proportion of first five years mother as a } \\
\text { child on a benefit }\end{array}$ & $\begin{array}{l}-0.063^{* * *} \\
(0.005)\end{array}$ & $\begin{array}{l}-0.145^{* * *} \\
(0.006)\end{array}$ \\
\hline School enrollment size/100 & $\begin{array}{l}0.002^{* * *} \\
(0.000)\end{array}$ & $\begin{array}{l}0.001^{* * * *} \\
(0.000)\end{array}$ \\
\hline School deciles 3 or 4 & $\begin{array}{c}0.006^{*} \\
(0.003) \\
\end{array}$ & $\begin{array}{l}0.011^{* *} \\
(0.005)\end{array}$ \\
\hline School deciles 5 or 6 & $\begin{array}{l}0.012^{* * *} \\
(0.004)\end{array}$ & $\begin{array}{l}0.024^{* * *} \\
(0.005)\end{array}$ \\
\hline School deciles 7 or 8 & $\begin{array}{l}0.034^{* * *} \\
(0.003)\end{array}$ & $\begin{array}{l}0.061^{* * *} \\
(0.005)\end{array}$ \\
\hline School deciles 9 or 10 & $\begin{array}{l}0.017^{* * * *} \\
(0.004)\end{array}$ & $\begin{array}{l}0.047^{* * *} \\
(0.005)\end{array}$ \\
\hline
\end{tabular}


Table 11A Continued

\begin{tabular}{|c|c|c|}
\hline South Auckland MOE office & $\begin{array}{c}0.021^{* * *} \\
(0.003)\end{array}$ & $\begin{array}{c}0.009^{*} \\
(0.005) \\
\end{array}$ \\
\hline Christchurch MOE office & $\begin{array}{c}0.030^{* * *} \\
(0.003)\end{array}$ & $\begin{array}{c}0.015^{\text {*** }} \\
(0.005)\end{array}$ \\
\hline Dunedin MOE office & $\begin{array}{l}0.046^{* * *} \\
(0.003)\end{array}$ & $\begin{array}{c}0.055^{\text {**** }} \\
(0.006)\end{array}$ \\
\hline Hamilton MOE office & $\begin{array}{c}0.033^{* * *} \\
(0.003)\end{array}$ & $\begin{array}{c}0.033^{\text {*** }} \\
(0.005)\end{array}$ \\
\hline Invercargill MOE office & $\begin{array}{c}0.025^{* * *} \\
(0.006)\end{array}$ & $\begin{array}{c}0.015 \\
(0.009)\end{array}$ \\
\hline Napier MOE office & $\begin{array}{l}0.036^{* * *} \\
(0.003)\end{array}$ & $\begin{array}{l}0.047^{\text {*** }} \\
(0.006)\end{array}$ \\
\hline Nelson MOE office & $\begin{array}{l}0.022^{* * *} \\
(0.005)\end{array}$ & $\begin{array}{c}0.016^{\text {** }} \\
(0.007)\end{array}$ \\
\hline Rotorua MOE office & $\begin{array}{c}0.033^{* * *} \\
(0.003)\end{array}$ & $\begin{array}{c}0.046^{* * * *} \\
(0.005)\end{array}$ \\
\hline Wellington MOE office & $\begin{array}{l}0.039^{* * *} \\
(0.003)\end{array}$ & $\begin{array}{c}0.043^{\text {**** }} \\
(0.005)\end{array}$ \\
\hline Whanganui MOE office & $\begin{array}{l}0.042^{* * *} \\
(0.003)\end{array}$ & $\begin{array}{c}0.037^{\text {*** }} \\
(0.006)\end{array}$ \\
\hline Whangarei MOE office & $\begin{array}{c}0.028^{* * *} \\
(0.006)\end{array}$ & $\begin{array}{l}0.031^{\text {*** }} \\
(0.007)\end{array}$ \\
\hline$n$ & 77,826 & 77,826 \\
\hline Log-likelihood function & $-22,837.7$ & $-34,544.4$ \\
\hline Likelihood-ratio $\chi^{2}$ statistic & $3,330.0$ & $4,427.9$ \\
\hline$p$-value $\chi^{2}$ test & 0.0000 & 0.0000 \\
\hline Pseudo $R^{2}$ statistic & 0.0680 & 0.0602 \\
\hline
\end{tabular}

Notes: These are the estimated marginal effects from the full regression. Standard errors in parentheses. See the notes at the bottom of Table 11 in the main body of this paper for more information on this estimation procedure.

*** Estimated partial derivative significantly different from zero at a $1 \%$ level using a $t$ test

** Estimated partial derivative significantly different from zero at a 5\% level using a $t$ test

* Estimated partial derivative significantly different from zero at a $10 \%$ level using a $t$ test 